\title{
Substituted 2-(3',4',5'-trimethoxybenzoyl)-benzo[b]thiophene derivatives as potent tubulin polymerization inhibitors
}

\author{
Romeo Romagnoli ${ }^{\mathrm{a}, *}$, Pier Giovanni Baraldi ${ }^{\mathrm{a}, *}$, Maria Dora Carrion ${ }^{\mathrm{a}}$, Olga Cruz-Lopez ${ }^{\mathrm{a}}$, Manlio Tolomeo ${ }^{\mathrm{b}}$, \\ Stefania Grimaudo ${ }^{b}$, Antonietta Di Cristina ${ }^{b}$, Maria Rosaria Pipitone ${ }^{\mathrm{b}}$, Jan Balzarini ${ }^{\mathrm{c}}$, Andrea Brancale ${ }^{\mathrm{d}}$, \\ Ernest Hamel ${ }^{\mathrm{e}}$
}

a Dipartimento di Scienze Farmaceutiche, Università di Ferrara, Via Fossato di Mortara 17-19, 44121 Ferrara, Italy

${ }^{\mathrm{b}}$ Dipartimento Biomedico di Medicina Interna e Specialistica, Università di Palermo, Palermo, Italy

${ }^{\mathrm{c}}$ Rega Institute for Medical Research, Laboratory of Virology and Chemotherapy, Minderbroedersstraat 10, B-3000 Leuven, Belgium

${ }^{\mathrm{d}}$ The Welsh School of Pharmacy, Cardiff University, King Edward VII Avenue, Cardiff, CF10 3NB, UK

e Screening Technologies Branch, Developmental Therapeutics Program, Division of Cancer Treatment and Diagnosis, National Cancer Institute at Frederick, National Institutes of Health, Frederick, Maryland 21702, USA

\section{A R T I C L E I N F O}

\section{Article history:}

Received 3 April 2010

Revised 25 May 2010

Accepted 25 May 2010

Available online 1 June 2010

\section{Keywords:}

Antiproliferative agents

Tubulin polymerization inhibitors

Microtubules

Antitumor

\begin{abstract}
A B S T R A C T
The central role of microtubules in cell division and mitosis makes them a particularly important target for anticancer agents. On our early publication, we found that a series of 2-( $3^{\prime}, 4^{\prime}, 5^{\prime}$-trimethoxybenzoyl)3 -aminobenzo[ $b$ ]thiophenes exhibited strong antiproliferative activity in the submicromolar range and significantly arrested cells in the G2-M phase of the cell cycle and induced apoptosis.

In order to investigate the importance of the amino group at the 3-position of the benzo[b]thiophene skeleton, the corresponding 3-unsubstituted and methyl derivatives were prepared. A novel series of inhibitors of tubulin polymerization, based on the 2-(3,4,5-trimethoxybenzoyl)-benzo[ $b]$ thiophene molecular skeleton with a methoxy substituent at the C-4, C-5, C-6 or C-7 position on the benzene ring, was evaluated for antiproliferative activity against a panel of five cancer cell lines, for inhibition of tubulin polymerization and for cell cycle effects. Replacing the methyl group at the C-3 position resulted in increased activity compared with the corresponding 3-unsubstituted counterpart. The structure-activity relationship established that the best activities were obtained with the methoxy group placed at the C-4, C-6 or C-7 position. Most of these compounds exhibited good growth inhibition activity and arrest K562 cells in the G2-M phase via microtubule depolymerization.
\end{abstract}

(c) 2010 Elsevier Ltd. All rights reserved.

\section{Introduction}

Besides being critical for cell architecture, the microtubule system of eukaryotic cells is essential for cell division, since microtubules are key components of the mitotic spindle. ${ }^{1}$ Microtubules also play a crucial role in a wide number of essential cellular processes, such as maintenance of cellular shape, regulation of motility, cell signaling, secretion and intracellular transport. ${ }^{2}$ In recent years, there has been an intense effort to identify and develop chemically diverse substances, many of which are derived from natural products, that inhibit tubulin assembly for treatment of cancer. ${ }^{3}$

Among the microtubule depolymerizing agents, combretastatin A-4 (CA4, 1; Chart 1) is one of the more studied compounds. CA4, isolated from the bark of the South African tree Combretum caffrum, ${ }^{4}$ strongly inhibits the polymerization of tubulin by binding

\footnotetext{
* Corresponding authors. Tel.: +39 (0)532 455303; fax: +39 (0)532 455953 (R.R.); tel.: +39 (0)532 291293; fax: 39 (0)532 455953 (P.G.B.)
}

E-mail addresses: rmr@unife.it (R. Romagnoli), baraldi@unife.it (P.G. Baraldi). to the colchicine site. ${ }^{5}$ The activity and structural simplicity of CA-4 have stimulated extensive studies to examine the structure-activity relationship (SAR) of this compound and its analogues. $^{6}$

Among the synthetic inhibitors of tubulin polymerization, there are limited examples of small molecules based on the benzo[ $b]$ thiophene molecular skeleton as the core structure. Pinney and coworkers described a series of tubulin binding agents with general structure 2, which incorporates the 3-( $3^{\prime}, 4^{\prime}, 5^{\prime}$-trimethoxybenzoyl)6-methoxy benzo[b]thiophene ring system. ${ }^{7}$ Previous studies have shown that the 6-methoxy substituent significantly contributes to maximize the activity of these compounds, presumably as a mimic of the 4-methoxy group in the B-ring of CA-4. ${ }^{6}$

We have recently reported the biological evaluation of a series of derivatives with general structure 3 , based on the $2-\left(3^{\prime}, 4^{\prime}, 5^{\prime}-\right.$ trimethoxybenzoyl)-3-aminobenzo[b]thiophene molecular skeleton. These compounds inhibited the growth of cancer cell lines and of tubulin polymerization by binding to the colchicine site of tubulin. As expected, these compounds caused cells to arrest in 


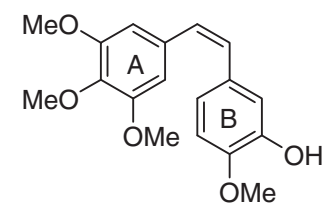

Combretastatin A-4 (CA-4), 1<smiles>[R]N(CCC)c1c(C(=O)c2cc(OC)c(OC)c(OC)c2)sc2c1C=C[R]C=C2</smiles>

3

$\mathrm{R}^{1}=\mathrm{H}, \mathrm{R}^{2}=4-\mathrm{OCH}_{3}, 3 \mathbf{a}$

$\mathrm{R}^{1}=\mathrm{H}, \mathrm{R}^{2}=5-\mathrm{OCH}_{3}, 3 \mathbf{b}$

$\mathrm{R}^{1}=\mathrm{H}, \mathrm{R}^{2}=6-\mathrm{OCH}_{3}, 3 \mathrm{c}$

$\mathrm{R}^{1}=\mathrm{H}, \mathrm{R}^{2}=7-\mathrm{OCH}_{3}$ 3d

$\mathrm{R}^{1}=\mathrm{CH}_{3}, \mathrm{R}^{2}=6-\mathrm{OCH}_{3}, 3 e$<smiles>[R]c1cc(-c2c(C(=O)c3cc(OC)c(OC)c(OC)c3)sc3cc(OC)ccc23)ccc1OC</smiles>

$\mathrm{R}=\mathrm{H}, \mathbf{2 a}$

$\mathrm{R}=\mathrm{OH}, 2 \mathrm{~b}$

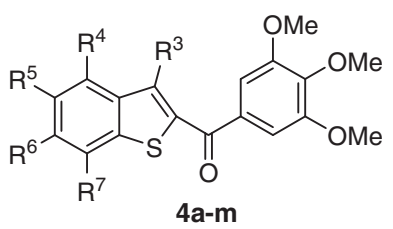

$\mathrm{R}^{3-7}=\mathrm{H}, \mathbf{4 a}$

$\mathrm{R}^{4}=\mathrm{OMe}, \mathrm{R}^{3,5-7}=\mathrm{H}, \mathbf{4 b}$

$\mathrm{R}^{5}=\mathrm{OMe}, \mathrm{R}^{3-4,6-7}=\mathrm{H}, \mathbf{4 c}$

$\mathrm{R}^{6}=\mathrm{OMe}, \mathrm{R}^{3-5,7}=\mathrm{H}, \mathbf{4 d}$

$\mathrm{R}^{7}=\mathrm{OMe}, \mathrm{R}^{3-6}=\mathrm{H}, 4 \mathrm{e}$

$\mathrm{R}^{3}=\mathrm{Me}, \mathrm{R}^{4-7}=\mathrm{H}, \mathbf{4 f}$

$\mathrm{R}^{3}=\mathrm{Me}, \mathrm{R}^{4}=\mathrm{OMe}, \mathrm{R}^{5-7}=\mathrm{H}, \mathbf{4 g}$

$\mathrm{R}^{3}=\mathrm{Me}, \mathrm{R}^{5}=\mathrm{OMe}, \mathrm{R}^{4,6-7}=\mathrm{H}, \mathbf{4 h}$

$\mathrm{R}^{3}=\mathrm{Me}, \mathrm{R}^{6}=\mathrm{OMe}, \mathrm{R}^{4-5,7}=\mathrm{H}, \mathbf{4 i}$

$\mathrm{R}^{3}=\mathrm{Me}, \mathrm{R}^{7}=\mathrm{OMe}, \mathrm{R}^{4-6}=\mathrm{H}, 4 \mathrm{j}$

$\mathrm{R}^{5,6}=\mathrm{OMe}, \mathrm{R}^{3-4,7}=\mathrm{H}, \mathbf{4 k}$

$\mathrm{R}^{3}=\mathrm{Me}, \mathrm{R}^{6}=\mathrm{OEt}, \mathrm{R}^{4-5,7}=\mathrm{H}, 4 \mathrm{I}$

$\mathrm{R}^{3}=\mathrm{Me}, \mathrm{R}^{6}=\mathrm{F}, \mathrm{R}^{4-5,7}=\mathrm{H}, 4 \mathrm{~m}$

Chart 1. Inhibitors of tubulin polymerization. (4a and 4f) or a methoxy group at each of the four possible positions on the benzene ring (compounds $\mathbf{4 b}-\mathbf{e}$ and $\mathbf{4 g - j}$ ). Keeping the C-6 methoxy group intact, compound $\mathbf{4 k}$ was prepared with the aim of evaluating the effect on biological activity of one additional methoxy substituent at the $C-5$ position. Finally, the 6 -methoxy position (corresponding to the 4-methoxy group in the B-ring of CA4) of $\mathbf{4} \mathbf{j}$ was further studied by synthesizing the corresponding 6-ethoxy (4l) and 6-fluorine (4m) analogues.

\section{Chemistry}

The 2-( $3^{\prime}, 4^{\prime}, 5^{\prime}$-trimethoxybenzoyl)benzo[ $\left.b\right]$ thiophene derivatives $\mathbf{4 a - m}$ were synthesized by the four step synthesis shown in Scheme 1 . Starting from the variously substituted salicylaldehydes 5b-e and 5k or 2-hydroxyacetophenones $\mathbf{5 f}-\mathbf{j}$ and $\mathbf{5 1 - \mathbf { m }}$, the reaction with $\mathrm{N}, \mathrm{N}$-dimethyl thiocarbamoyl chloride in $\mathrm{N}, \mathrm{N}$-dimethylformamide (DMF) in the presence of DABCO yielded the $O$-arylthiocarbamates $\mathbf{6 b}-\mathbf{m}$ in good yields. These latter were submitted to Newman-Kwart rearrangement ${ }^{9}$ by heating under microwave irradiation (MW) in the absence of solvent, to furnish the corresponding $S$-arylthiocarbamates $\mathbf{7 b}-\mathbf{m}$. The subsequent hydrolysis using a $3 \mathrm{M}$ aqueous sodium hydroxide solution furnished the desired 2-thiophenols $\mathbf{8 b}-\mathbf{m}$, which were used without further purification for the next reaction. 2-Mercaptobenzaldehyde $8 \mathbf{a}$ was obtained by S-debenzylation of 2-benzylthiobenzaldehyde with aluminum chloride. This latter compound was obtained by condensation of 2-nitrobenzaldehyde $\mathbf{5 a}$ with the potassium salt of phenyl methanethiol in cold aqueous DMF. ${ }^{10}$

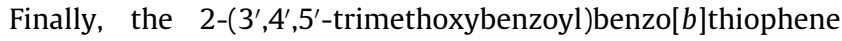
derivatives $\mathbf{4 a - m}$ were synthesized by a 'one-step' condensation, followed by intramolecular cyclization, of 8a-m with 2-bromo-1(3,4,5-trimethoxyphenyl)ethanone using anhydrous potassium carbonate in refluxing acetone.

\section{Biological results and discussion}

phase of the cell cycle. ${ }^{8}$ Potent activity appears to be highly dependent upon the presence and position of a fourth methoxy substituent on benzo $[b]$ thiophene system. A fairly dramatic difference was observed between C-4/5 and C-6/7-substituted compounds (3a-b and $\mathbf{3} \mathbf{c}-\mathbf{d}$, respectively). The greatest activity occurred when the methoxy group was located at the C- 6 or C-7 position, the least when located at the $\mathrm{C}-4$ or $\mathrm{C}-5$ position $\left(\mathrm{IC}_{50}\right.$ $>10 \mu \mathrm{M})$. The slight reduction in potency of the 3-dimethylamino derivative $\mathbf{3 e}$, which did not differ significantly from that of the 3-amino counterpart 3c, allowed us to verify that an intramolecular hydrogen bond between the unsubstituted 3-amino group and the carbonyl oxygen of the 2-trimethoxybenzoyl moiety is not required for activity. These encouraging results prompted us to study this class of compounds in more detail. We herein describe the

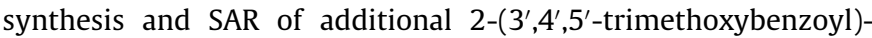
benzo[ $b]$ thiophene derivatives in continuation of our search for new potent antitubulin agents.

In the present investigation, the $3^{\prime}, 4^{\prime}, 5^{\prime}$-trimethoxyphenyl of the 2-benzoyl moiety was kept unchanged because it is the characteristic structural requirement for activity in numerous inhibitors of tubulin polymerization, such as colchicine, CA4 and podophyllotoxin. ${ }^{6}$ In the current studies we examined the importance of the 3 -position of the benzo[ $b]$ thiophene skeleton by studying the effects of replacing the amino or dimethylamino substituents of compounds with general structure $\mathbf{3}$ with a hydrogen or a methyl group, to furnish derivatives with general structure 4 . The SAR was elucidated with electron-donating methoxy substitution at the C-4, $\mathrm{C}-5, \mathrm{C}-6$ or $\mathrm{C}-7$ position on the benzo[b]thiophene ring.

In the series of compounds $\mathbf{4 a - j}$, the 3 -amino group of the benzo[b]thiophene system was replaced by hydrogen $(\mathbf{4 a - e})$ or methyl $(\mathbf{4} \mathbf{f}-\mathbf{j})$. These molecules possessed either no substituent
Table 1 summarizes the growth inhibitory effects of $2-\left(3^{\prime}, 4^{\prime}, 5^{\prime}-\right.$ trimethoxy)benzo[b]thiophene derivatives $\mathbf{4 a - m}$ against murine leukemia (L1210), murine mammary carcinoma (FM3A), human T-lymphoblastoid (Molt/4 and CEM) and human cervix carcinoma (HeLa) cells, with 3-amino-2-( $3^{\prime}, 4^{\prime}, 5^{\prime}$-trimethoxy)benzo[b]thiophene counterparts 3a-d and CA4 (1) as reference compounds. Five compounds (4b, $\mathbf{4 e}, \mathbf{4 g}, \mathbf{4 i}$ and $\mathbf{4 j}$ ) displayed strong growth inhibitory activity, with $\mathrm{IC}_{50}$ values lower than $100 \mathrm{nM}$ against all 5 cell lines. In addition, $\mathbf{4 f}, \mathbf{4 1}$ and $\mathbf{4 m}$ yielded $\mathrm{IC}_{50}$ values below $100 \mathrm{nM}$ in one to three cell lines. The 3-methyl-4-methoxy derivative $4 \mathrm{~g}$ possessed the highest potency, inhibiting the growth of L1210, FM3A, Molt/4, CEM and HeLa cells with IC ${ }_{50}$ values of 19 , $23,18,19$ and $16 \mathrm{nM}$, respectively. These values were similar to those obtained with CA4 against FM3A and Molt4 cells, while $\mathbf{4 g}$ was 5-10-fold less active than CA-4 against L1210, CEM and HeLa cells. Compound $\mathbf{4 g}$ also showed at least 100 -fold greater activity than its 4-methoxy-3-amino-2-( $3^{\prime}, 4^{\prime}, 5^{\prime}$-trimethoxy)benzo[b]thiophene counterpart 3a.

Comparing the 3-unsubstituted derivatives 4a-e with their 3methyl congeners $\mathbf{4 f}-\mathbf{j}$, the introduction of a methyl at the C-3 position of the benzo[b]thiophene system generally increased antiproliferative activity against all five cell lines. The methoxy substitution and location on the benzene part of benzo[b]thiophene moiety plays an important role in affecting antiproliferative activity. In both these series, the methoxy group located at the C-4 or C-7 position enhanced activity, while the C-5 and C-6 substituents were detrimental.

In the series of 3 -unsubstituted derivatives $\mathbf{4 b} \mathbf{b}-\mathbf{e}$, there was an evident difference in activity between the C-4/7 and the C-5/6 
<smiles>[R]C(=O)c1c([R7])c([R7])c([R8])c([2H])c1[2H]</smiles>

5b-m a

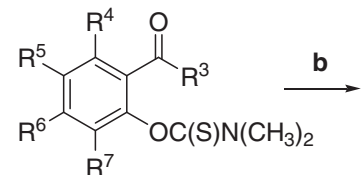

6b-m

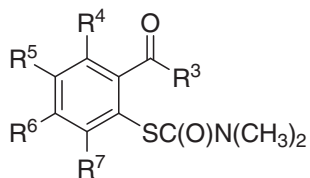

7b-m

c<smiles>[R7]C(=O)c1c([R7])c([10BH2])c([10BH2])c([10BH2])c1[10BH2]</smiles>

$\mathrm{R}^{3-7}=\mathrm{H}, 4-5 \mathrm{a}, 8 \mathrm{a}$

$\mathrm{R}^{4}=\mathrm{OMe}, \mathrm{R}^{3,5-7}=\mathrm{H}, \mathbf{4 - 8 b}$

$\mathrm{R}^{5}=\mathrm{OMe}, \mathrm{R}^{3-4,6-7}=\mathrm{H}, 4-8 \mathrm{c}$

$\mathrm{R}^{6}=\mathrm{OMe}, \mathrm{R}^{3-5,7}=\mathrm{H}, \mathbf{4 - 8 d}$

$\mathrm{R}^{7}=\mathrm{OMe}, \mathrm{R}^{3-6}=\mathrm{H}, 4-8 \mathrm{e}$

$R^{3}=\mathrm{Me}, \mathrm{R}^{4-7}=\mathrm{H}, \mathbf{4 - 8 f}$

$\mathrm{R}^{3}=\mathrm{Me}, \mathrm{R}^{4}=\mathrm{OMe}, \mathrm{R}^{5-7}=\mathrm{H}, \mathbf{4 - 8} \mathrm{g}$

$\mathrm{R}^{3}=\mathrm{Me}, \mathrm{R}^{5}=\mathrm{OMe}, \mathrm{R}^{4,6-7}=\mathrm{H}, 4-8 \mathrm{~h}$

$\mathrm{R}^{3}=\mathrm{Me}, \mathrm{R}^{6}=\mathrm{OMe}, \mathrm{R}^{4-5,7}=\mathrm{H}, 4-8$

$R^{3}=\mathrm{Me}, \mathrm{R}^{7}=\mathrm{OMe}, \mathrm{R}^{4-6}=\mathrm{H}, \mathbf{4 - 8 \mathrm { j }}$

$\mathrm{R}^{5,6}=\mathrm{OMe}, \mathrm{R}^{3-4,7}=\mathrm{H}, \mathbf{4 - 8} \mathbf{k}$

$\mathrm{R}^{3}=\mathrm{Me}, \mathrm{R}^{6}=\mathrm{OEt}, \mathrm{R}^{4-5,7}=\mathrm{H}, 4-8 \mathrm{I}$

$\mathrm{R}^{3}=\mathrm{Me}, \mathrm{R}^{6}=\mathrm{F}, \mathrm{R}^{4-5,7}=\mathrm{H}, 4-8 \mathrm{~m}$<smiles>[R7]C(=O)c1c([R7])c([R7])c([R7])c([N+](=O)[O-])c1[R]</smiles>

5 a

Scheme 1. Reagents and conditions. (a) $\mathrm{ClC}(\mathrm{S}) \mathrm{N}\left(\mathrm{CH}_{3}\right)_{2}$, Dabco, DMF, $50{ }^{\circ} \mathrm{C}, 5 \mathrm{~h}$; (b) no solvent, heating of fused substrates, microwaves; (c) $\mathrm{NaOH}$, EtOH/H2O, $65{ }^{\circ} \mathrm{C}$; (d) $(3,4,5-$ trimethoxyphenyl)-2-bromo-ethanone, $\mathrm{K}_{2} \mathrm{CO}_{3},\left(\mathrm{CH}_{3}\right)_{2} \mathrm{CO}$, rx; (e) $\mathrm{C}_{6} \mathrm{H}_{5} \mathrm{CH}_{2} \mathrm{SH}$, KOH, DMF; (f) $\mathrm{AlCl}_{3}, \mathrm{C}_{6} \mathrm{H}_{6}$.

Table 1

In vitro inhibitory effects of compounds $\mathbf{3 a - d}, \mathbf{4 a - m}$ and $\mathbf{C A 4}$ against the proliferation of murine leukemia (L1210), murine mammary carcinoma (FM3A), human T-lymphocyte (Molt/4 and CEM) and human cervix carcinoma (HeLa) cells

\begin{tabular}{lccccc}
\hline Compound & \multicolumn{5}{c}{$\mathrm{IC}_{50}{ }^{\mathrm{a}}(\mathrm{nM})$} \\
\cline { 2 - 6 } & $\mathrm{L} 1210$ & $\mathrm{FM} 3 \mathrm{~A} / 0$ & $\mathrm{Molt} 4 / \mathrm{C} 8$ & $\mathrm{CEM} / 0$ & Hela \\
\hline 3a & $>10,000$ & $>10,000$ & $>10,000$ & $>10,000$ & n.d. \\
$\mathbf{3 b}$ & $>10,000$ & $>10,000$ & $>10,000$ & $>10,000$ & n.d. \\
3c & $39 \pm 16$ & $46 \pm 12$ & $10 \pm 7$ & $7.7 \pm 2.9$ & n.d. \\
$\mathbf{3 d}$ & $33 \pm 29$ & $27 \pm 13$ & $8.5 \pm 1.4$ & $8.9 \pm 2.0$ & n.d. \\
$\mathbf{4 a}$ & $490 \pm 40$ & $860 \pm 16$ & $500 \pm 31$ & $510 \pm 17$ & $1100 \pm 100$ \\
$\mathbf{4 b}$ & $87 \pm 5$ & $99 \pm 0$ & $75 \pm 6$ & $83 \pm 9$ & $75 \pm 5$ \\
$\mathbf{4 c}$ & $580 \pm 15$ & $790 \pm 18$ & $2100 \pm 300$ & $3000 \pm 100$ & $900 \pm 23$ \\
$\mathbf{4 d}$ & $1200 \pm 200$ & $1500 \pm 0$ & $550 \pm 14$ & $1700 \pm 40$ & $590 \pm 32$ \\
$\mathbf{4 e}$ & $84 \pm 5$ & $85 \pm 4$ & $27 \pm 2$ & $46 \pm 7$ & $24 \pm 1$ \\
$\mathbf{4 f}$ & $140 \pm 20$ & $190 \pm 30$ & $93 \pm 5$ & $94 \pm 5$ & $99 \pm 1$ \\
$\mathbf{4 g}$ & $19 \pm 2$ & $23 \pm 7$ & $18 \pm 0$ & $19 \pm 1$ & $16 \pm 1$ \\
$\mathbf{4 h}$ & $600 \pm 10$ & $550 \pm 10$ & $430 \pm 10$ & $500 \pm 50$ & $460 \pm 10$ \\
$\mathbf{4 i}$ & $30 \pm 2$ & $45 \pm 2$ & $18 \pm 0$ & $19 \pm 1$ & $18 \pm 2$ \\
$\mathbf{4 j}$ & $25 \pm 4$ & $35 \pm 4$ & $28 \pm 2$ & $18 \pm 4$ & $21 \pm 1$ \\
$\mathbf{4 k}$ & $1100 \pm 60$ & $980 \pm 53$ & $440 \pm 14$ & $350 \pm 15$ & $220 \pm 16$ \\
$\mathbf{4 l}$ & $100 \pm 0$ & $130 \pm 10$ & $56 \pm 2$ & $56 \pm 3$ & $140 \pm 24$ \\
$\mathbf{4 m}$ & $130 \pm 20$ & $140 \pm 9$ & $94 \pm 8$ & $110 \pm 10$ & $110 \pm 13$ \\
CA4 & $2.8 \pm 1.1$ & $42 \pm 6.0$ & $16 \pm 1.4$ & $1.9 \pm 1.6$ & $1.9 \pm 1.6$ \\
\hline
\end{tabular}

n.d. $=$ not determined

a $\mathrm{IC}_{50}=$ compound concentration required to inhibit tumor cell proliferation by $50 \%$. Data are expressed as the mean \pm SE from the dose-response curves of at least three independent experiments.

methoxy derivatives. Our findings showed that the methoxy group located at the C-4 or at the C-7 position (4b and $4 \mathbf{e}$, respectively) resulted, on average, in antiproliferative activity, 19-fold greater than with the methoxy group at the C-5 or C-6 position (4b and $\mathbf{4 e}$ vs $\mathbf{4 c}$ and $\mathbf{4 d}$ ). The $\mathrm{C}-5 / 6$ dimethoxy derivative $\mathbf{4 k}$ had activity on average about twice that of either $\mathbf{4 c}$ or $\mathbf{4 d}$, and $\mathbf{4 k}$ was particularly more active than either monosubstituted compound in the CEM/0 and HeLa cells.
A different effect was observed in the series of 3-methyl substituted derivatives $\mathbf{4 g} \mathbf{- j}$, in which the greatest activity occurred when the methoxy group was located at the C-4, C- 6 or C-7 position, the least when it was located at the $\mathrm{C}-5$ position. The $\mathrm{C}-3$ methyl, C-6 methoxy derivative (4i) was selected as a scaffold for further modifications, by replacing the methoxy group with either an ethoxy group (41) or an electron-withdrawing fluorine atom $(\mathbf{4 m})$. Both these changes resulted in a decrease in antiproliferative activity against all cell lines relative to $\mathbf{4 i}$, but overall compounds $4 \mathbf{1}$ and $\mathbf{4 m}$ had very similar activity despite the significant difference in the chemical properties of the two C-6 substituents.

The marked improvement in activity of $\mathbf{4 g}$ relative to 4 -methoxy-3-amino-2-(3', $4^{\prime}, 5^{\prime}$-trimethoxybenzoyl)benzo[ $\left.b\right]$ thiophene derivative 3a derives from the substitution of an amino with a methyl group at the $\mathrm{C}-3$ position of the $2-\left(3^{\prime}, 4^{\prime}, 5^{\prime}\right.$-trimethoxy)benzo[b]thiophene core.

Comparing the 4-methoxy derivatives $\mathbf{3 a}, \mathbf{4 b}$ and $\mathbf{4 g}$, the order of activity for the substituent at the 3-position of the benzo[b]thiophene moiety was methyl $(\mathbf{4 g})>$ hydrogen $(\mathbf{4 b}) \gg$ amino (3a). With these three compounds, $\mathrm{IC}_{50}$ values were $16-23 \mathrm{nM}$ for $\mathbf{4 g}$ and 75-99 nM for $\mathbf{4 b}$, while for $\mathbf{3 a}$ all $\mathrm{IC}_{50}$ 's were greater than $10 \mu \mathrm{M}$. Comparing the C-6 and C-7 methoxy derivatives 3cd and $\mathbf{4 i j}$, replacement of the 3 -amino group with a methyl resulted in minimal loss of activity. Thus, with a C-4 methoxy group, the C-3 substituent had a much greater impact on antiproliferative activity than was the case with either a C-6 or C-7 methoxy substituent. With the latter compounds, in which the benzo[b]thiophene methoxy substituent is more distant from the trimethoxybenzene ring, the ortho relationship between the $3^{\prime}, 4^{\prime}, 5^{\prime}$-trimethoxybenzoyl moiety and the C-3 amino group does not play an important role in activity. Thus the 3-amino function can be removed and replaced with a hydrogen or a methyl without significant change in activity.

Because $\mathbf{3 c}$ and $\mathbf{3 d}$ inhibited tubulin assembly, ${ }^{8}$ we next investigated whether the antiproliferative activities of the new 
compounds were related to an interaction with the microtubule system. Compounds $\mathbf{4 b}, \mathbf{4 e}-\mathbf{g}, \mathbf{4 i}-\mathbf{j}$ and $\mathbf{4 1 m}$ were evaluated for their in vitro inhibition of the polymerization of $10 \mu \mathrm{M}$ tubulin and for their inhibitory effects on the binding of $\left[{ }^{3} \mathrm{H}\right]$ colchicine to tubulin (in the latter assay, tubulin was examined at a concentration of $1 \mu \mathrm{M}$, while colchicine was at $5 \mu \mathrm{M}) .{ }^{11,12}$ For comparison, derivatives 3cd and CA4 were examined in contemporaneous experiments as a reference compounds (Table 2). All tested compounds strongly inhibited tubulin assembly and derivatives $\mathbf{4 e}$, 4f, $4 \mathrm{~g}$ and $4 \mathrm{~m}$, with $\mathrm{IC}_{50}$ values of $0.58-0.71 \mu \mathrm{M}$, exhibited antitubulin activity about $1.5-2$ times greater than that of CA4 $\left(\mathrm{IC}_{50}\right.$, $1.0 \mu \mathrm{M}$ ), while $\mathbf{4 b}, \mathbf{4 i}, \mathbf{4 j}$ and $\mathbf{4 1}$ had $\mathrm{IC}_{50}$ values of $0.92-1.2 \mu \mathrm{M}$, essentially equivalent to that of CA4 and 3c. Comparing the 7methoxy benzo $[b]$ thiophene derivatives $\mathbf{3 d}, \mathbf{4 e}$ and $\mathbf{4 j}$, the 3 -amino compound 3d was less effective than 3-unsubstituted and 3methyl analogues $\mathbf{4 e}$ and $\mathbf{4 j}$, respectively, as an inhibitor of tubulin polymerization.

Compounds $\mathbf{4 f}$ and $\mathbf{4 m}$ were almost 1.5 -fold more active than CA4 as inhibitors of tubulin assembly, although both compounds were less active in their effects on cell growth.

In the colchicine studies, all compounds were active inhibitors of the binding reaction. Compound $\mathbf{4 g}$, the agent with the greatest antiproliferative activity, was the most active inhibitor of the binding of $\left[{ }^{3} \mathrm{H}\right]$ colchicine to tubulin, since $85 \%$ and $93 \%$ inhibition occurred with this agent at 1 and $5 \mu \mathrm{M}$, respectively. Compound $\mathbf{4 g}$ was as active as CA4, which in these experiments inhibited colchicine binding by $88 \%$ and $99 \%$. Although 4 e was almost twice as active as $4 \mathbf{i}$ as an inhibitor of tubulin polymerization, these two compounds showed similar activity as inhibitors of colchicine binding.

While this group of compounds were all highly potent in the biological assays (inhibition of cell growth, tubulin assembly and colchicine binding), correlations between the three assay types were imperfect. Thus, while compound $\mathbf{4 e}$ was the best inhibitor of tubulin assembly, its effect on colchicine binding was matched by compounds $\mathbf{4 i}$ and $\mathbf{4 j}$, both of which were almost half as active as assembly inhibitors. Compound $\mathbf{4 e}$ was, in general, somewhat less effective as an inhibitor of cell growth than the other two compounds $\mathbf{4 i}$ and $\mathbf{4 j}$.

Because molecules exhibiting effects on tubulin assembly should cause alteration of cell cycle parameters, with preferential G2-M blockade, flow cytometry analysis was performed to determine the effect of compounds $\mathbf{4 b}, \mathbf{4 e}-\mathbf{g}, \mathbf{4 i}-\mathbf{j}$ and $\mathbf{4 1 - m}$ on $\mathrm{K} 562$ (human chronic myelogenous leukemia) cells, which are usually

Table 2

Inhibition of tubulin polymerization and colchicine binding by compounds 3c-d, 4b, 4e-g, 4i-j, 4l-m and CA4

\begin{tabular}{|c|c|c|c|}
\hline \multirow[t]{2}{*}{ Compound } & \multirow[t]{2}{*}{$\begin{array}{l}\text { Tubulin assembly } \\
\mathrm{IC}_{50} \pm \mathrm{SD}(\mu \mathrm{M})\end{array}$} & \multicolumn{2}{|c|}{$\begin{array}{c}\text { Colchicine } \\
\text { binding } \% \pm \text { SD }\end{array}$} \\
\hline & & $\begin{array}{l}1 \mu \mathrm{M} \\
\text { drug }\end{array}$ & $\begin{array}{l}5 \mu \mathrm{M} \\
\text { drug }\end{array}$ \\
\hline $3 c$ & $1.3 \pm 0.1$ & $60 \pm 0.1$ & n.d. \\
\hline 3d & $2.1 \pm 0.3$ & $39 \pm 1$ & n.d. \\
\hline $4 b$ & $1.2 \pm 0.07$ & $49 \pm 1$ & $81 \pm 4$ \\
\hline $4 e$ & $0.58 \pm 0.02$ & $60 \pm 0.3$ & $88 \pm 0.5$ \\
\hline 4f & $0.63 \pm 0.1$ & $51 \pm 2$ & $88 \pm 4$ \\
\hline $4 g$ & $0.67 \pm 0.1$ & $85 \pm 7$ & $93 \pm 5$ \\
\hline $4 i$ & $0.92 \pm 0.05$ & $66 \pm 4$ & $92 \pm 0.3$ \\
\hline $4 j$ & $0.95 \pm 0.06$ & $54 \pm 3$ & $87 \pm 1$ \\
\hline 41 & $0.93 \pm 0.01$ & n.d. & $75 \pm 3$ \\
\hline $4 m$ & $0.71 \pm 0.1$ & $48 \pm 2$ & $80 \pm 1$ \\
\hline CA4 (1) & $1.0 \pm 0.09$ & $88 \pm 1$ & $99 \pm 2$ \\
\hline
\end{tabular}

employed by our research group to determine the alteration of cell cycle parameters following exposure to antitumour compounds. ${ }^{13}$ Cells were cultured for $24 \mathrm{~h}$ in the presence of each compound at the concentration able to inhibit cell growth $100 \%$ after $24 \mathrm{~h}$. Analysis of sub- $G_{0}-G_{1}$ (apoptotic peak, A), $G_{0}-G_{1}, S$, and $G 2-M$ peaks revealed that the compounds caused somewhat different effects on cell cycle distribution (Table 3). After a $24 \mathrm{~h}$ treatment, all tested compounds caused a massive accumulation of cells in the G2-M phase (51-82\%) relative to the untreated control (15.1\%), with a simultaneous decrease of cells in the S and G0-G1. With compound $\mathbf{4 e}$, the accumulation of cells in $\mathrm{G} 2-\mathrm{M}$ phase was accompanied by the appearance of a significant sub- $\mathrm{G}_{0}-\mathrm{G}_{1}$ peak ( $A=17.7 \%)$ due to apoptosis.

A set of molecular docking calculations was also performed to investigate the possible binding mode of this series of compounds. All the compounds reported in Table 1 were docked in the colchicine binding site of tubulin. The majority of the compounds showed a binding pose similar to the one observed with the cocrystallized DAMA-colchicine, with the trimethoxyphenyl ring placed in proximity of Cys241 (residue numbering derived from the crystal structure used). In addition, the benzo[b]thiophene ring is placed deep in the pocket, interacting with tubulin through a series of hydrophobic contacts (Fig. 1). In addition, the benzo[b]thiophene ring is placed deep in the pocket, interacting with tubulin through a series of hydrophobic contacts (Fig. 1). Compounds 3a-b, 4c-d, $\mathbf{4 h}$ and $\mathbf{4 l}$ either did not dock with the trimethoxyphenyl in contact with Cys241 or they docked outside the binding pocket, hence their results were not further analyzed. For compounds

Table 3

Effects of compounds $\mathbf{4 b}, \mathbf{4 e}-\mathbf{g}, \mathbf{4 i}-\mathbf{j}$ and $\mathbf{4 1 -} \mathbf{m}$ on K562 cell cycle progression

\begin{tabular}{|c|c|c|c|c|c|c|}
\hline \multirow[t]{2}{*}{ Compound } & \multirow[t]{2}{*}{$\mathrm{IC}_{50}^{\mathrm{a}}(\mathrm{nM})$} & \multirow[t]{2}{*}{$\mathrm{IC}_{100}{ }^{\mathrm{b}}(\mathrm{nM})$} & \multicolumn{4}{|c|}{ Cell cycle distribution (\%) } \\
\hline & & & Sub-G $1^{c}$ & G0G1 & $\mathrm{S}$ & $\mathrm{G} 2 / \mathrm{M}$ \\
\hline Control & & & 3.76 & 34.6 & 50.4 & 15.1 \\
\hline $4 b$ & $220 \pm 50$ & 800 & 8.28 & 2.13 & 18.9 & 78.9 \\
\hline $4 e$ & $95 \pm 2$ & 150 & 17.7 & 14.8 & 26.8 & 58.3 \\
\hline $4 f$ & $180 \pm 20$ & 500 & 6.00 & 3.72 & 13.8 & 82.5 \\
\hline $4 \mathrm{~g}$ & $38 \pm 7$ & 85 & 7.92 & 3.74 & 16.9 & 79.4 \\
\hline $4 i$ & $6 \pm 0.1$ & 25 & 7.80 & 11.7 & 22.1 & 66.2 \\
\hline $4 j$ & $42 \pm 5$ & 75 & 9.46 & 4.19 & 15.2 & 80.6 \\
\hline 41 & $47 \pm 8$ & 230 & 11.2 & 10.8 & 38.1 & 51.2 \\
\hline $4 m$ & $220 \pm 40$ & 400 & 10.5 & 6.16 & 17.1 & 76.7 \\
\hline
\end{tabular}

a Compound concentration required to inhibit tumor cell proliferation by $50 \%$. Data are expressed as the mean \pm SE from the dose-response curves of at least three independent experiments.

b Compound concentration required to inhibit tumor cell proliferation by $100 \%$.

c Percentage of the cell population with hypodiploid DNA content peak (apoptotic cells).

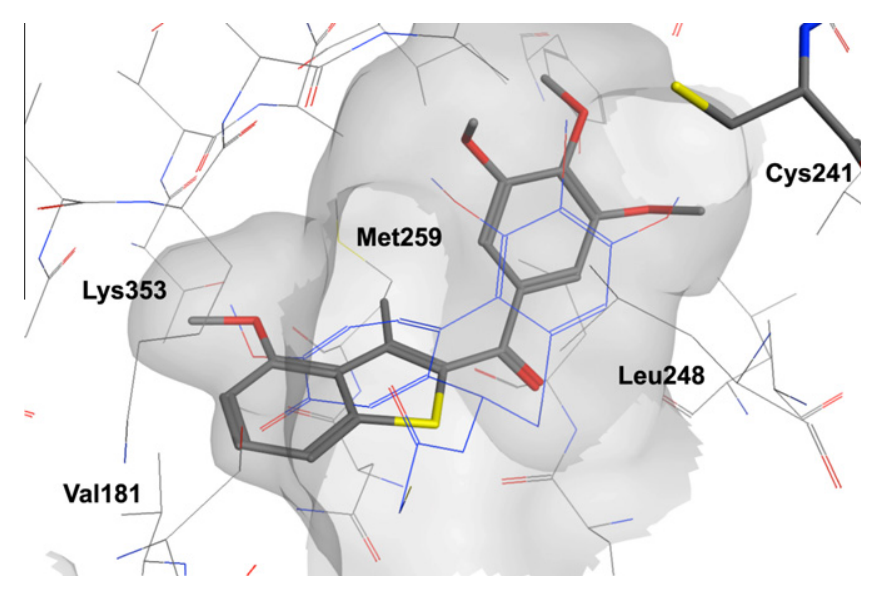

Figure 1. Presumptive binding mode of 4g. DAMA-colchicine in blue. 
3c-d, the benzo $[b]$ thiophene was placed with the amino group oriented on the same side of the carbonyl linker, allowing a possible intramolecular hydrogen bond (see Fig. 1 in Supplementary data). In the case of methyl substituted analogues $(\mathbf{4 f}-\mathbf{j})$, it is often the sulfur atom that is oriented on the same side of the carbonyl group, allowing, in the case of compound $\mathbf{4 g}$, the positioning of the methoxy substituent in position 4 on the heterocyclic ring to overlap well with the corresponding moiety on ring $\mathrm{C}$ of the colchicine analogue (Fig. 1). In particular, the methoxy group establishes a nonpolar interaction deep in the biding pocket, in contact with Val181, which appear to be important for biological activity. Compound $\mathbf{4 j}$ showed a similar orientation of the heterocyclic ring to the one observed for 3c-d and also in this case, the methoxy substituent is in contact with Val181. It should also be noted that a similar binding pose was observed for the series of benzo[ $b]$ furan derivatives we have recently reported. ${ }^{14}$

\section{Conclusions}

In continuing experiments to optimize the $2-\left(3^{\prime}, 4^{\prime}, 5^{\prime}\right.$-trimethoxybenzoyl)-3-aminobenzo[b]thiophene core structure, we developed a new series of compounds with general structure 4 , in which the 3-amino moiety was replaced with a hydrogen or methyl group. The results suggest that the hydrophobic methyl group is a good surrogate for the 3-amino moiety and resulted in an improvement in antiproliferative activity. Maximal activity was dependent on the location of the methoxy substituent on the benzene part of benzo[b]thiophene moiety. The SAR study showed that a single methoxy group located at the C-4 or C-7 position resulted in the best activity, while activity was decreased when the methoxy group was located at the C -5 position.

In the series of derivatives without a substituent at C-3, the C-5 and C-6 methoxy derivatives were significantly less active than C-4 and $\mathrm{C}-7$ positional isomers. In the 3-methyl series, compounds with the methoxy group at the C-4, C-6 and C-7 position exhibited about 20 -fold greater activity than the $\mathrm{C}-5$ methoxy isomer.

The most active compound in this series was the $2-\left(3^{\prime}, 4^{\prime}, 5^{\prime}-\right.$ trimethoxybenzoyl)-3-methyl-4-methoxybenzo[ $b]$ thiophene derivative $\mathbf{4 g}$, with $\mathrm{IC}_{50}$ antiproliferative values of 16-23 nM. Compound $\mathbf{4 g}$ also showed at least 100 -fold greater activity than its 4-methoxy-3-amino-2-(3',4',5'-trimethoxy)benzo[ $b]$ thiophene counterpart 3a. Compound $\mathbf{4 g}$ was a potent inhibitor of tubulin polymerization, with an $\mathrm{IC}_{50}$ of $0.67 \mu \mathrm{M}$, and it arrested $\mathrm{K} 562$ cancer cells in the G2-M phase of the cell cycle. Several additional compounds (4e, $\mathbf{4 f}, \mathbf{4 g}$ and $\mathbf{4 m}$ ) were more potent than CA4 as inhibitors of tubulin assembly. Nevertheless, except for $\mathbf{4 g}$, all members of the series were less active than CA4 as inhibitors of the binding of $\left[{ }^{3} \mathrm{H}\right]$ colchicine to tubulin. As a consequence of their interactions with tubulin, all compounds examined caused cell cycle arrest in the G2-M phase, with an increase from the control value of $15 \%$ to $51-82 \%$ of cells in G2-M. This is well supported by the molecular modeling studies, where it was observed that the methoxy group in these positions could occupy an hydrophobic region deep in the binding pocket.

\section{Experimental}

\subsection{Chemistry}

\subsubsection{Materials and methods}

2-Nitrobenzaldehyde (5a), 2-hydroxy-6-methoxybenzaldehyde (5b), 2-hydroxy-5-methoxybenzaldehyde (5c), 2-hydroxy-4-methoxybenzaldehyde (5d), 2-hydroxy-3z-methoxybenzaldehyde (5e), 1-(2-hydroxyphenyl)ethanone (5f), 2-hydroxy-6-methoxyacetophenone (5g), 2-hydroxy-5-methoxyacetophenone (5h), 2-hydroxy-4-methoxyacetophenone (5i), 2-hydroxy-3-methoxy- acetophenone (5j), 2-hydroxy-4-ethoxyacetophenone (51), 2-hydroxy-4-fluoroacetophenone $(\mathbf{5 m})$ are commercially available and were used as received. For the preparation of 2-hydroxy-4,5dimethoxybenzaldehyde (5k) see: Foyer, R.; Rene, L.; Cavier, R.; Lemoine, J. Eur. J. Med. Chem. 1977, 12, 455.

${ }^{1} \mathrm{H}$ NMR spectra were recorded on a Bruker AC 200 spectrometer. Chemical shifts $(\delta)$ are given in ppm upfield from tetramethylsilane as internal standard, and the spectra were recorded in appropriate deuterated solvents, as indicated. Melting points (mp) were determined on a Buchi-Tottoli apparatus and are uncorrected. All products reported showed ${ }^{1} \mathrm{H}$ NMR spectra in agreement with the assigned structures. Elemental analyses were conducted by the Microanalytical Laboratory of the Chemistry Department of the University of Ferrara. Mass spectra were obtained by electrospray ionization (ESI) in positive mode using an ESI Micromass ZMD 2000 mass spectrometer. All reactions were carried out under an inert atmosphere of dry nitrogen, unless otherwise described. Standard syringe techniques were applied for transferring dry solvents. Reaction courses and product mixtures were routinely monitored by TLC on silica gel (precoated $\mathrm{F}_{254}$ Merck plates) and visualized with aqueous $\mathrm{KMnO}_{4}$. Flash chromatography was performed using 230-400 mesh silica gel and the indicated solvent system. Organic solutions were dried over anhydrous $\mathrm{Na}_{2} \mathrm{SO}_{4}$. Calcium chloride was used in the distillation of DMF, and the distilled solvent was stored over molecular sieves ( $3 \AA$ A). The MW reaction was performed in a focused MW oven (Discover, CEM, $2450 \mathrm{MHz}$ ).

\subsection{General procedure (A) for the synthesis of compounds $6 \mathrm{~b}-\mathrm{m}$}

To a solution of phenol $\mathbf{5 b} \mathbf{b}-\mathbf{m}(5 \mathrm{mmol})$ in $8 \mathrm{~mL}$ of DMF containing DABCO (1.68 g, $15 \mathrm{mmol}$ ) was added $\mathrm{N}, \mathrm{N}$-dimethylthiocarbamyl chloride $(1.85 \mathrm{~g}, 15 \mathrm{mmol})$ in one portion. The temperature rose rapidly to $50{ }^{\circ} \mathrm{C}$, and the mixture was held at this temperature for $5 \mathrm{~h}$. After this time, the mixture was poured into water $(30 \mathrm{~mL})$ and the product was extracted with dichloromethane $(3 \times$ $30 \mathrm{~mL}$ ). The combined organic phases were washed with $5 \% \mathrm{HCl}$ $(20 \mathrm{~mL}), 0.1 \mathrm{M} \mathrm{NaOH}(20 \mathrm{~mL})$ and brine $(20 \mathrm{~mL})$, dried over $\mathrm{Na}_{2} \mathrm{SO}_{4}$ and concentrated under reduced pressure. The residue was purified by flash column chromatography on silica gel.

\subsubsection{O-2-Formyl-3-methoxyphenyl $N, N$-dimethylcarb- amothioate (6b)}

The residue was chromatographed with EtOAc-petroleum ether 2:8 as eluent to give $\mathbf{6 b}$ as a white solid, yield: $79 \%, \mathrm{mp} 119-121^{\circ} \mathrm{C}$. ${ }^{1} \mathrm{H}$ NMR $\left(\mathrm{CDCl}_{3}\right) \delta: 3.43(\mathrm{~s}, 3 \mathrm{H}), 3.48(\mathrm{~s}, 3 \mathrm{H}), 3.87(\mathrm{~s}, 3 \mathrm{H}), 7.19(\mathrm{~d}$, $J=8.0 \mathrm{~Hz}, 1 \mathrm{H}), 7.35(\mathrm{t}, J=7.6 \mathrm{~Hz}, 1 \mathrm{H}), 7.49(\mathrm{~d}, J=8.0 \mathrm{~Hz}, 1 \mathrm{H}), 10.1$ $(\mathrm{s}, 1 \mathrm{H})$.

\subsubsection{O-2-Formyl-4-methoxyphenyl $N, N$-dimethylcarb- amothioate (6c)}

The residue was chromatographed with EtOAc-petroleum ether $3: 7$ as eluent to give $\mathbf{6 c}$ as a white solid, yield: $92 \%, \mathrm{mp} 87-89^{\circ} \mathrm{C}$. ${ }^{1} \mathrm{H}$ NMR $\left(\mathrm{CDCl}_{3}\right) \delta: 3.41(\mathrm{~s}, 3 \mathrm{H}), 3.47(\mathrm{~s}, 3 \mathrm{H}), 3.86(\mathrm{~s}, 3 \mathrm{H}), 7.03(\mathrm{~d}$, $J=8.8 \mathrm{~Hz}, 1 \mathrm{H}), 7.15(\mathrm{~d}, J=8.8 \mathrm{~Hz}, 1 \mathrm{H}), 7.37(\mathrm{~s}, 1 \mathrm{H}), 10.0(\mathrm{~s}, 1 \mathrm{H})$.

\subsubsection{O-2-Formyl-5-methoxyphenyl $N, N$-dimethylcarb- amothioate (6d)}

The residue was chromatographed with EtOAc-petroleum ether 3:7 as eluent to give $\mathbf{6 d}$ as a yellow solid, yield: $72 \%, \mathrm{mp} 91-93^{\circ} \mathrm{C}$. ${ }^{1} \mathrm{H}$ NMR $\left(\mathrm{CDCl}_{3}\right) \delta: 3.41(\mathrm{~s}, 3 \mathrm{H}), 3.47(\mathrm{~s}, 3 \mathrm{H}), 3.88(\mathrm{~s}, 3 \mathrm{H}), 6.63(\mathrm{~s}$, $1 \mathrm{H}), 6.91(\mathrm{~d}, J=8.8 \mathrm{~Hz}, 1 \mathrm{H}), 7.83(\mathrm{~d}, J=8.8 \mathrm{~Hz}, 1 \mathrm{H}), 9.91(\mathrm{~s}, 1 \mathrm{H})$.

\subsubsection{O-2-Formyl-6-methoxyphenyl $N, N$-dimethylcarb- amothioate (6e)}

The residue was chromatographed with EtOAc-petroleum ether 3:7 as eluent to give $6 \mathbf{e}$ as a white solid, yield: $72 \%, \mathrm{mp} 142-144{ }^{\circ} \mathrm{C}$. 
${ }^{1} \mathrm{H}$ NMR $\left(\mathrm{CDCl}_{3}\right) \delta: 3.40(\mathrm{~s}, 3 \mathrm{H}), 3.46(\mathrm{~s}, 3 \mathrm{H}), 3.94(\mathrm{~s}, 3 \mathrm{H}), 6.70(\mathrm{~d}$, $J=8.0 \mathrm{~Hz}, 1 \mathrm{H}), 6.89(\mathrm{~d}, J=8.0 \mathrm{~Hz}, 1 \mathrm{H}), 7.56(\mathrm{t}, J=8.2 \mathrm{~Hz}, 1 \mathrm{H}), 10.3$ $(\mathrm{s}, 1 \mathrm{H})$.

\subsection{5. $\mathbf{O}$-2-Acetylphenyl $\mathbf{N}, \mathbf{N}$-dimethylcarbamothioate (6f)}

The residue was chromatographed with EtOAc-petroleum ether $1: 9$ as eluent to give $\mathbf{6 f}$ as a white solid, yield: $95 \%, \mathrm{mp} 77-79{ }^{\circ} \mathrm{C} .{ }^{1} \mathrm{H}$ $\operatorname{NMR}\left(\mathrm{CDCl}_{3}\right) \delta: 2.66(\mathrm{~s}, 3 \mathrm{H}), 3.36(\mathrm{~s}, 3 \mathrm{H}), 3.45(\mathrm{~s}, 3 \mathrm{H}), 7.07$ (d, $J=8.2 \mathrm{~Hz}, 1 \mathrm{H}), 7.32(\mathrm{t}, J=7.2 \mathrm{~Hz}, 1 \mathrm{H}), 7.57$ (t, $J=7.2 \mathrm{~Hz}, 1 \mathrm{H}), 7.80$ $(\mathrm{d}, J=8.2 \mathrm{~Hz}, 1 \mathrm{H})$.

\subsubsection{O-2-Acetyl-3-methoxyphenyl $N, N$-dimethylcarb- amothioate (6g)}

The residue was chromatographed with EtOAc-petroleum ether $2: 8$ as eluent to give $\mathbf{6 g}$ as a white solid, yield: $79 \%, \mathrm{mp} 89-92{ }^{\circ} \mathrm{C}$. ${ }^{1} \mathrm{H}$ NMR $\left(\mathrm{CDCl}_{3}\right) \delta: 2.53(\mathrm{~s}, 3 \mathrm{H}), 3.29(\mathrm{~s}, 3 \mathrm{H}), 3.39(\mathrm{~s}, 3 \mathrm{H}), 3.86(\mathrm{~s}$, $3 \mathrm{H}), 6.68(\mathrm{~d}, J=8.4 \mathrm{~Hz}, 1 \mathrm{H}), 6.81(\mathrm{~d}, J=8.4 \mathrm{~Hz}, 1 \mathrm{H}), 7.35(\mathrm{~d}$, $J=8.4 \mathrm{~Hz}, 1 \mathrm{H})$.

\subsubsection{O-2-Acetyl-4-methoxyphenyl $\mathrm{N}, \mathrm{N}$-dimethylcarb- amothioate $(6 h)$}

The residue was chromatographed with EtOAc-petroleum ether 2:8 as eluent to give $\mathbf{6 h}$ as a white solid, yield: $94 \%, \mathrm{mp} 83-85^{\circ} \mathrm{C}$. ${ }^{1} \mathrm{H}$ NMR $\left(\mathrm{CDCl}_{3}\right) \delta: 2.52(\mathrm{~s}, 3 \mathrm{H}), 3.38(\mathrm{~s}, 3 \mathrm{H}), 3.45(\mathrm{~s}, 3 \mathrm{H}), 3.84(\mathrm{~s}$, $3 \mathrm{H}), 7.01(\mathrm{~s}, 1 \mathrm{H}), 7.04(\mathrm{~m}, 1 \mathrm{H}), 7.29(\mathrm{~m}, 1 \mathrm{H})$.

\subsubsection{O-2-Acetyl-5-methoxyphenyl $\mathrm{N}, \mathrm{N}$-dimethylcarb- amothioate (6i)}

The residue was chromatographed with EtOAc-petroleum ether 2:8 as eluent to give $\mathbf{6 i}$ as colourless oil, yield: $95 \% .{ }^{1} \mathrm{H} \mathrm{NMR}\left(\mathrm{CDCl}_{3}\right)$ $\delta: 1.42(\mathrm{t}, J=7.0 \mathrm{~Hz}, 3 \mathrm{H}), 2.49(\mathrm{~s}, 3 \mathrm{H}), 3.39(\mathrm{~s}, 3 \mathrm{H}), 3.46(\mathrm{~s}, 3 \mathrm{H}), 4.04$ $(\mathrm{q}, J=7.0 \mathrm{~Hz}, 2 \mathrm{H}), 6.56(\mathrm{~d}, J=2.6 \mathrm{~Hz}, 1 \mathrm{H}), 6.84(\mathrm{dd}, J=2.6$ and $8.8 \mathrm{~Hz}, 1 \mathrm{H}), 7.80(\mathrm{~d}, J=8.8 \mathrm{~Hz}, 1 \mathrm{H})$.

\subsubsection{O-2-Acetyl-6-methoxyphenyl $N, N$-dimethylcarb- amothioate $(6 \mathbf{j})$}

The residue was chromatographed with EtOAc-petroleum ether 2:8 as eluent to give $\mathbf{6 j}$ as a white solid, yield: $78 \%, \mathrm{mp} 144-146{ }^{\circ} \mathrm{C}$. ${ }^{1} \mathrm{H}$ NMR $\left(\mathrm{CDCl}_{3}\right) \delta: 2.55(\mathrm{~s}, 3 \mathrm{H}), 3.40(\mathrm{~s}, 3 \mathrm{H}), 3.46(\mathrm{~s}, 3 \mathrm{H}), 3.84(\mathrm{~s}$, $3 \mathrm{H}), 7.12(\mathrm{~d}, J=8.0 \mathrm{~Hz}, 1 \mathrm{H}), 7.27(\mathrm{t}, J=8.4 \mathrm{~Hz}, 1 \mathrm{H}), 7.36(\mathrm{~d}$, $J=8.4 \mathrm{~Hz}, 1 \mathrm{H})$.

\subsubsection{O-2-Formyl-4,5-dimethoxyphenyl $\mathrm{N}, \mathrm{N}$-dimethylcarb- amothioate (6k)}

The residue was chromatographed with EtOAc-petroleum ether $3: 7$ as eluent to give $\mathbf{6 k}$ as a white solid, yield: $69 \%$, mp $172-$ $174{ }^{\circ} \mathrm{C} .{ }^{1} \mathrm{H} \mathrm{NMR}\left(\mathrm{CDCl}_{3}\right) \delta$ : $3.42(\mathrm{~s}, 3 \mathrm{H}), 3.48(\mathrm{~s}, 3 \mathrm{H}), 3.94(\mathrm{~s}, 6 \mathrm{H})$, $6.61(\mathrm{~s}, 1 \mathrm{H}), 7.36(\mathrm{~s}, 1 \mathrm{H}), 9.94(\mathrm{~s}, 1 \mathrm{H})$.

\subsubsection{O-2-Acetyl-5-ethoxyphenyl $\mathrm{N}, \mathrm{N}$-dimethylcarb- amothioate (61)}

The residue was chromatographed with EtOAc-petroleum ether 2:8 as eluent to give $\mathbf{6 l}$ as a white solid, yield: $81 \%, \mathrm{mp} 84-86{ }^{\circ} \mathrm{C} .{ }^{1} \mathrm{H}$ $\operatorname{NMR}\left(\mathrm{CDCl}_{3}\right) \delta: 2.48(\mathrm{~s}, 3 \mathrm{H}), 3.38(\mathrm{~s}, 3 \mathrm{H}), 3.45(\mathrm{~s}, 3 \mathrm{H}), 3.84(\mathrm{~s}, 3 \mathrm{H})$, $6.58(\mathrm{~d}, J=2.8 \mathrm{~Hz}, 1 \mathrm{H}), 6.84(\mathrm{dd}, J=2.4$ and $8.8 \mathrm{~Hz}, 1 \mathrm{H}), 7.80(\mathrm{~d}$, $J=8.8 \mathrm{~Hz}, 1 \mathrm{H})$.

\subsubsection{2. $\mathrm{O}$-2-Acetyl-5-fluorophenyl $\mathrm{N}, \mathrm{N}$-dimethylcarbamothioate (6m)}

The residue was chromatographed with EtOAc-petroleum ether $3: 7$ as eluent to give $\mathbf{6 m}$ as a colourless oil, yield: $90 \% .{ }^{1} \mathrm{H}$ NMR $\left(\mathrm{CDCl}_{3}\right) \delta: 2.52(\mathrm{~s}, 3 \mathrm{H}), 3.39(\mathrm{~s}, 3 \mathrm{H}), 3.45(\mathrm{~s}, 3 \mathrm{H}), 6.85(\mathrm{dd}, J=2.8$ and $7.0 \mathrm{~Hz}, 1 \mathrm{H}), 7.03(\mathrm{~m}, 1 \mathrm{H}), 7.82(\mathrm{dd}, J=6.4$ and $8.8 \mathrm{~Hz}, 1 \mathrm{H})$.

\subsection{General procedure (B) for the synthesis of compounds $7 \mathrm{~b}-\mathrm{m}$}

The $N, N$-dimethylcarbamothioate $\mathbf{6 b}-\mathbf{m}(0.5 \mathrm{mmol})$ was placed in a $10 \mathrm{~mL}$ closed vial and irradiated in a focused MW oven at the conditions described for each compound. The progress of the reaction was followed by thin-layer chromatography. The reaction mixture was then cooled and purified by flash column chromatography on silica gel.

\subsubsection{S-2-Formyl-3-methoxyphenyl $N, N$-dimethylcarb- amothioate (7b)}

MW irradiation conditions: power $(P): 200 \mathrm{~W}$, temperature $(T)$ : $210{ }^{\circ} \mathrm{C}$, ramp time (RT): 2 min; time: 2 min. The residue was chromatographed with EtOAc-petroleum ether 3:7 as eluent to give $\mathbf{7 b}$ as a yellow oil, yield: $60 \% .{ }^{1} \mathrm{H}$ NMR $\left(\mathrm{CDCl}_{3}\right) \delta: 3.01(\mathrm{~s}, 3 \mathrm{H}), 3.13(\mathrm{~s}$, $3 \mathrm{H}), 3.90(\mathrm{~s}, 3 \mathrm{H}), 7.02$ (d, $J=8.4 \mathrm{~Hz}, 1 \mathrm{H}), 7.21(\mathrm{~d}, J=8.4 \mathrm{~Hz}, 1 \mathrm{H})$, $7.47(\mathrm{t}, J=8.4 \mathrm{~Hz}, 1 \mathrm{H}), 10.5(\mathrm{~s}, 1 \mathrm{H})$.

\subsubsection{S-2-Formyl-4-methoxyphenyl $\mathrm{N}, \mathrm{N}$-dimethylcarb- amothioate (7c)}

MW conditions: P: $280 \mathrm{~W}, \mathrm{~T}: 240^{\circ} \mathrm{C}, \mathrm{RT}: 2 \mathrm{~min}$; time: $1 \mathrm{~min}$. The residue was chromatographed with EtOAc-petroleum ether 2:8 as eluent to give $7 \mathrm{c}$ as a yellow oil, yield: $48 \% .{ }^{1} \mathrm{H}$ NMR $\left(\mathrm{CDCl}_{3}\right) \delta: 3.03$ (s, 3H), 3.16 (s, 3H), 3.87 (s, 3H), 7.12 (d, J=8.2 Hz, 1H), 7.46 (d, $J=8.2 \mathrm{~Hz}, 1 \mathrm{H}), 7.52(\mathrm{~s}, 1 \mathrm{H}), 10.3(\mathrm{~s}, 1 \mathrm{H})$.

\subsubsection{S-2-Formyl-5-methoxyphenyl $\mathrm{N}, \mathrm{N}$-dimethylcarb- amothioate (7d)}

MW conditions: P: $280 \mathrm{~W}, \mathrm{~T}: 170^{\circ} \mathrm{C}, \mathrm{RT}: 2 \mathrm{~min}$; time: $10 \mathrm{~min}$. The residue was chromatographed with EtOAc-petroleum ether 3:7 as eluent to give 7d as a white solid, yield: 92\%, mp 81$83{ }^{\circ} \mathrm{C} .{ }^{1} \mathrm{H}$ NMR $\left(\mathrm{CDCl}_{3}\right) \delta: 3.02(\mathrm{~s}, 3 \mathrm{H}), 3.17(\mathrm{~s}, 3 \mathrm{H}), 3.87(\mathrm{~s}, 3 \mathrm{H})$, 7.07 (d, $J=8.4 \mathrm{~Hz}, 1 \mathrm{H}), 7.08(\mathrm{~s}, 1 \mathrm{H}), 8.01(\mathrm{~d}, J=8.4 \mathrm{~Hz}, 1 \mathrm{H}), 10.25$ (s, $1 \mathrm{H})$.

\subsubsection{S-2-Formyl-6-methoxyphenyl $\mathrm{N}, \mathrm{N}$-dimethylcarb- amothioate (7e)}

MW conditions: $P$ : $200 \mathrm{~W}, \mathrm{~T}: 210^{\circ} \mathrm{C}, \mathrm{RT}$ : 2 min; time: $2 \mathrm{~min}$. The residue was chromatographed with EtOAc-petroleum ether 3:7 as eluent to give 7e as a yellow oil, yield: $67 \% .{ }^{1} \mathrm{H} \mathrm{NMR}\left(\mathrm{CDCl}_{3}\right) \delta: 3.01$ $(\mathrm{s}, 3 \mathrm{H}), 3.21(\mathrm{~s}, 3 \mathrm{H}), 4.31(\mathrm{~s}, 3 \mathrm{H}), 7.18(\mathrm{~d}, J=8.0 \mathrm{~Hz}, 1 \mathrm{H}), 7.52(\mathrm{t}$, $J=8.4 \mathrm{~Hz}, 1 \mathrm{H}), 7.62(\mathrm{~d}, J=8.4 \mathrm{~Hz}, 1 \mathrm{H}), 10.4(\mathrm{~s}, 1 \mathrm{H})$.

\subsection{5. $S$-2-Acetylphenyl $N, N$-dimethylcarbamothioate (7f)}

MW conditions: $P: 200 \mathrm{~W}, \mathrm{~T}: 210^{\circ} \mathrm{C}, \mathrm{RT}: 2 \mathrm{~min}$; time: $3 \mathrm{~min}$. The residue was chromatographed with EtOAc-petroleum ether 2:8 as eluent to give $7 \mathbf{f}$ as a brown oil, yield: $61 \% .{ }^{1} \mathrm{H}$ NMR $\left(\mathrm{CDCl}_{3}\right) \delta: 2.57$ (s, 3H), 3.04 (s, 3H), 3.07 (s, 3H), 7.45 (m, 2H), 7.59 (m, 2H).

\subsubsection{S-2-Acetyl-3-methoxyphenyl $N, N$-dimethylcarb- amothioate (7g)}

MW conditions: P: $200 \mathrm{~W}, \mathrm{~T}: 210^{\circ} \mathrm{C}, \mathrm{RT}: 2 \mathrm{~min}$; time: $5 \mathrm{~min}$. The residue was chromatographed with EtOAc-petroleum ether 4:6 as eluent to give $7 \mathbf{g}$ as a brown oil, yield: $82 \% .{ }^{1} \mathrm{H}$ NMR $\left(\mathrm{CDCl}_{3}\right) \delta: 2.46$ (s, 3H), $2.99(\mathrm{~s}, 3 \mathrm{H}), 3.02(\mathrm{~s}, 3 \mathrm{H}), 3.79(\mathrm{~s}, 3 \mathrm{H}), 6.92(\mathrm{~d}, J=8.4 \mathrm{~Hz}, 1 \mathrm{H})$, $7.11(\mathrm{~d}, J=8.4 \mathrm{~Hz}, 1 \mathrm{H}), 7.27(\mathrm{t}, J=8.4 \mathrm{~Hz}, 1 \mathrm{H})$.

\subsubsection{S-2-Acetyl-4-methoxyphenyl $N, N$-dimethylcarb- amothioate (7h)}

MW conditions: $P$ : $280 \mathrm{~W}, \mathrm{~T}: 240^{\circ} \mathrm{C}, \mathrm{RT}: 2 \mathrm{~min}$; time: $1 \mathrm{~min}$. The residue was chromatographed with EtOAc-petroleum ether 4:6 as eluent to give $\mathbf{7 h}$ as a brown oil, yield: $53 \% .{ }^{1} \mathrm{H} \mathrm{NMR}\left(\mathrm{CDCl}_{3}\right) \delta: 2.56$ $(\mathrm{s}, 3 \mathrm{H}), 3.04(\mathrm{~s}, 3 \mathrm{H}), 3.10(\mathrm{~s}, 3 \mathrm{H}), 3.83(\mathrm{~s}, 3 \mathrm{H}), 6.95(\mathrm{~d}, J=8.6 \mathrm{~Hz}, 1 \mathrm{H})$, $6.99(\mathrm{~s}, 1 \mathrm{H}), 7.44(\mathrm{~d}, J=8.6 \mathrm{~Hz}, 1 \mathrm{H})$.

\subsection{8. $S$-2-Acetyl-5-methoxyphenyl $N, N$-dimethylcarb- amothioate (7i)}

MW conditions: P: $200 \mathrm{~W}, \mathrm{~T}: 210^{\circ} \mathrm{C}$, RT: $2 \mathrm{~min}$; time: $4 \mathrm{~min}$. The residue was chromatographed with EtOAc-petroleum ether 4:6 as eluent to give $7 \mathbf{i}$ as a brown oil, yield: $51 \% .{ }^{1} \mathrm{H}$ NMR 
$\left(\mathrm{CDCl}_{3}\right) \delta: 2.56(\mathrm{~s}, 3 \mathrm{H}), 3.04(\mathrm{~s}, 3 \mathrm{H}), 3.09(\mathrm{~s}, 3 \mathrm{H}), 3.84(\mathrm{~s}, 3 \mathrm{H})$, $6.89(\mathrm{~d}, J=2.8$ and $8.8 \mathrm{~Hz}, 1 \mathrm{H}), 7.14(\mathrm{~d}, J=2.6 \mathrm{~Hz}, 1 \mathrm{H}), 7.65(\mathrm{~d}$, $J=8.6 \mathrm{~Hz}, 1 \mathrm{H})$.

\subsubsection{S-2-Acetyl-6-methoxyphenyl $\mathrm{N}, \mathrm{N}$-dimethylcarb- amothioate $(7 \mathbf{j})$}

MW conditions: P: $240 \mathrm{~W}, \mathrm{~T}: 210^{\circ} \mathrm{C}, \mathrm{RT}: 2 \mathrm{~min}$; time: $2 \mathrm{~min}$. The residue was chromatographed with EtOAc-petroleum ether $2: 8$ as eluent to give $7 \mathbf{j}$ as a brown oil, yield: $69 \% .{ }^{1} \mathrm{H}$ NMR $\left(\mathrm{CDCl}_{3}\right) \delta: 2.58$ $(\mathrm{s}, 3 \mathrm{H}), 2.96(\mathrm{~s}, 3 \mathrm{H}), 3.24(\mathrm{~s}, 3 \mathrm{H}), 4.24(\mathrm{~s}, 3 \mathrm{H}), 7.12(\mathrm{~d}, J=8.0 \mathrm{~Hz}, 1 \mathrm{H})$, $7.48(\mathrm{t}, J=8.4 \mathrm{~Hz}, 1 \mathrm{H}), 7.58(\mathrm{~d}, J=8.4 \mathrm{~Hz}, 1 \mathrm{H})$.

\subsubsection{0. $S$-2-Formyl-4,5-dimethoxyphenyl $N, N$-dimethylcarb- amothioate (7k)}

MW conditions: P: $300 \mathrm{~W}, \mathrm{~T}: 240^{\circ} \mathrm{C}, \mathrm{RT}: 2 \mathrm{~min}$; time: $4 \mathrm{~min}$. The residue was chromatographed with EtOAc-petroleum ether $1: 1$ as eluent to give $7 \mathbf{k}$ as a yellow oil, yield: $55 \% .{ }^{1} \mathrm{H} \mathrm{NMR}\left(\mathrm{CDCl}_{3}\right) \delta: 3.03$ (s, 3H), 3.16 (s, 3H), 3.96 (s, 6H), 6.99 (s, 1H), 7.54 (s, 1H), 10.3 (s, $1 \mathrm{H})$.

\subsubsection{S-2-Acetyl-5-ethoxyphenyl $\mathrm{N}, \mathrm{N}$-dimethylcarbamothioate} (71)

MW conditions: $P$ : $280 \mathrm{~W}, \mathrm{~T}: 220^{\circ} \mathrm{C}, \mathrm{RT}: 2 \mathrm{~min}$; time: $2 \mathrm{~min}$. The residue was chromatographed with EtOAc-petroleum ether 2:8 as eluent to give 71 as a brown oil, yield: $53 \% .{ }^{1} \mathrm{H} \mathrm{NMR}\left(\mathrm{CDCl}_{3}\right) \delta: 1.41$ (t, $J=7.0 \mathrm{~Hz}, 3 \mathrm{H}), 2.56(\mathrm{~s}, 3 \mathrm{H}), 3.04(\mathrm{~s}, 3 \mathrm{H}), 3.09(\mathrm{~s}, 3 \mathrm{H}), 4.09(\mathrm{q}$, $J=7.0 \mathrm{~Hz}, 2 \mathrm{H}), 6.87(\mathrm{~d}, J=2.8$ and $8.6 \mathrm{~Hz}, 1 \mathrm{H}), 7.14(\mathrm{~d}, J=2.6 \mathrm{~Hz}$, $1 \mathrm{H}), 7.65(\mathrm{~d}, J=8.6 \mathrm{~Hz}, 1 \mathrm{H})$

\subsubsection{S-2-Acetyl-5-fluorophenyl $\mathrm{N}, \mathrm{N}$-dimethylcarbamothioate} (7m)

MW conditions: P: $240 \mathrm{~W}, \mathrm{~T}: 210^{\circ} \mathrm{C}$, RT: $1 \mathrm{~min}$; time: $4 \mathrm{~min}$. The residue was chromatographed with EtOAc-petroleum ether 3:7 as eluent to give $7 \mathbf{m}$ as a brown oil, yield: $78 \% .{ }^{1} \mathrm{H}$ NMR $\left(\mathrm{CDCl}_{3}\right) \delta: 2.58(\mathrm{~s}, 3 \mathrm{H}), 3.04(\mathrm{~s}, 3 \mathrm{H}), 3.08(\mathrm{~s}, 3 \mathrm{H}), 7.12(\mathrm{~m}, 1 \mathrm{H})$, $7.36(\mathrm{dd}, J=2.6$ and $8.8 \mathrm{~Hz}, 1 \mathrm{H}), 7.64(\mathrm{dd}, J=5.6$ and $8.6 \mathrm{~Hz}$, $1 \mathrm{H})$.

\subsection{Synthesis of 2-(benzylthio) benzaldehyde}

To a cold solution (ice bath) containing 2-nitrobenzaldehyde $(3.0 \mathrm{~g}, 20 \mathrm{mmol})$ and benzylmercaptan $(2.48 \mathrm{~g}, 20 \mathrm{mmol})$ in $20 \mathrm{~mL}$ of DMF was added dropwise a solution of $\mathrm{KOH}(2 \mathrm{~g}$, $36 \mathrm{mmol}$ ) in $5 \mathrm{~mL}$ of water. The mixture was stirred at $4{ }^{\circ} \mathrm{C}$ for $2 \mathrm{~h}$ and then poured into ice-water. The solid was collected, washed with cold water $(50 \mathrm{~mL})$, dried in vacuo over $\mathrm{P}_{2} \mathrm{O}_{5}$ and recrystallised from petroleum ether. Yield: $76 \%$, brown oil. ${ }^{1} \mathrm{H}$ NMR (CDCl3) $\delta: 4.13(\mathrm{~s}, 2 \mathrm{H}), 7.28(\mathrm{~m}, 6 \mathrm{H}), 7.33(\mathrm{t}, J=8.0 \mathrm{~Hz}, 1 \mathrm{H})$, $7.49(\mathrm{~m}, 1 \mathrm{H}), 7.82(\mathrm{~d}, J=4.4 \mathrm{~Hz}, 1 \mathrm{H}), 10.2(\mathrm{~s}, 1 \mathrm{H})$.

\subsection{Synthesis of 2-mercaptobenzaldehyde (8a)}

A solution of 2-benzylthiobenzaldehyde $(4.56 \mathrm{~g}, 20 \mathrm{mmol})$ in dry benzene $(40 \mathrm{~mL})$ was added dropwise over $30 \mathrm{~min}$ to a suspension of finely powdered anhydrous aluminium chloride $(4.5 \mathrm{~g}$, $33 \mathrm{mmol})$ in dry benzene $(40 \mathrm{~mL})$, and the mixture was stirred under nitrogen at room temperature for $48 \mathrm{~h}$. The green-brown mixture was decomposed by the cautious addition of ice-water $(100 \mathrm{~mL})$, and the organic layer was separated and washed successively with water $(50 \mathrm{~mL})$ and $5 \%$ aqueous sodium hydroxide $(2 \times 50 \mathrm{~mL})$. The alkaline extracts were acidified $(\mathrm{pH} 2)$ and extracted with dichloromethane $(3 \times 50 \mathrm{~mL})$. The organic extracts were washed with brine, dried and evaporated to yield 2-mercaptobenzaldehyde as a brown oil, yield: $24 \% .{ }^{1} \mathrm{H}$ NMR $\left(\mathrm{CDCl}_{3}\right) \delta$ : $7.31(\mathrm{~m}, 2 \mathrm{H}), 7.33(\mathrm{t}, J=8.0 \mathrm{~Hz}, 1 \mathrm{H}), 7.82(\mathrm{~d}, J=4.4 \mathrm{~Hz}, 1 \mathrm{H}), 10.1$ (s, 1H), $10.4(\mathrm{~s}, 1 \mathrm{H})$.

\subsection{General procedure $(\mathrm{C})$ for the synthesis of 2-thiophenols 8b-m}

The $S$-aryl compound $\mathbf{7 b} \mathbf{b}-\mathbf{m}$ ( $3 \mathrm{mmol})$ was dissolved in $\mathrm{MeOH}$ $(10 \mathrm{~mL})$. A $3 \mathrm{~N}$ aqueous solution of $\mathrm{NaOH}(12 \mathrm{~mL})$ was added, and the reaction mixture was heated to reflux for $2 \mathrm{~h}$. The reaction mixture was cooled to $25^{\circ} \mathrm{C}$ and acidified to $\mathrm{pH} 5$ by the addition of $10 \%$ aqueous $\mathrm{HCl}$. The resulting mixture was extracted with EtOAc $(3 \times 15 \mathrm{~mL})$, and the combined organic extracts were washed with brine, dried over $\mathrm{Na}_{2} \mathrm{SO}_{4}$ and concentrated in vacuo to furnish the corresponding 2-mercaptoarylaldehyde, which was used without further purification for the next reaction.

\subsection{General procedure (D) for the synthesis of $2-\left(3^{\prime}, 4^{\prime}, 5^{\prime}\right.$-trim- ethoxybenzoyl) benzo[b]thiophenes $4 \mathrm{a}-\mathrm{m}$}

To a solution of the appropriate substituted 2-mercaptobenzadehyde $\mathbf{8 b - e}$ and $\mathbf{8 k}$ or 2-mercaptoacetophenone $\mathbf{8 f}-\mathbf{j}$ and $\mathbf{8 1 m}$ $(1 \mathrm{mmol})$ in dry acetone $(15 \mathrm{~mL})$ was added 2-bromo-1-(3,4,5-trimethoxyphenyl)ethanone ( $289 \mathrm{mg}, 1 \mathrm{mmol}$ ) and anhydrous potassium carbonate ( $276 \mathrm{mg}, 2 \mathrm{mmol}$ ) while stirring, and the reaction mixture was refluxed for $18 \mathrm{~h}$. After cooling, the reaction mixture was evaporated, and the residue was dissolved in a mixture of dichloromethane $(15 \mathrm{~mL})$ and water $(5 \mathrm{~mL})$. The organic layer was washed with brine, dried and concentrated under reduced pressure to obtain a residue, which was purified by flash column chromatography.

\subsection{1. (Benzo[b]thiophen-2-yl)(3,4,5-trimethoxyphenyl) methanone (4a)}

The residue was chromatographed with EtOAc-petroleum ether 1.5:8.5 as eluent to give $\mathbf{4 a}$ as a white solid, yield: $96 \%, \mathrm{mp} 113-$ $115{ }^{\circ} \mathrm{C} .{ }^{1} \mathrm{H}$ NMR $\left(\mathrm{CDCl}_{3}\right) \delta$ : $3.93(\mathrm{~s}, 6 \mathrm{H}), 3.96(\mathrm{~s}, 3 \mathrm{H}), 7.19(\mathrm{~s}, 2 \mathrm{H})$, 7.42 (t, $J=8.0 \mathrm{~Hz}, 1 \mathrm{H}), 7.52$ (t, $J=8.0 \mathrm{~Hz}, 1 \mathrm{H}), 7.92(\mathrm{~m}, 3 \mathrm{H})$. Anal. Calcd for $\mathrm{C}_{18} \mathrm{H}_{16} \mathrm{O}_{4} \mathrm{~S}$ : C, 65.84; H, 4.91. Found: C, 65.72; H, 4.78.

\subsection{2. (4-Methoxybenzo[b]thiophen-2-yl)(3,4,5-trimethoxy- phenyl)methanone (4b)}

The residue was chromatographed with EtOAc-petroleum ether 2:8 as eluent to give $\mathbf{4 b}$ as a white solid, yield: $55 \%, \mathrm{mp} 163-165{ }^{\circ} \mathrm{C}$. ${ }^{1} \mathrm{H} \mathrm{NMR}\left(\mathrm{CDCl}_{3}\right) \delta: 3.92(\mathrm{~s}, 3 \mathrm{H}), 3.93(\mathrm{~s}, 6 \mathrm{H}), 3.96(\mathrm{~s}, 3 \mathrm{H}), 6.77(\mathrm{dd}$, $J=7.6$ and $1.0 \mathrm{~Hz}, 1 \mathrm{H}), 7.19(\mathrm{~s}, 2 \mathrm{H}), 7.44(\mathrm{~m}, 2 \mathrm{H}), 8.07(\mathrm{~s}, 1 \mathrm{H})$. Anal. Calcd for $\mathrm{C}_{19} \mathrm{H}_{18} \mathrm{O}_{5} \mathrm{~S}$ : C, 63.76; H, 5.06. Found: C, 63.56; H, 4.98.

\subsection{3. (5-Methoxybenzo[b]thiophen-2-yl)(3,4,5-trimethoxy-} phenyl)methanone (4c)

The residue was chromatographed with EtOAc-petroleum ether 3:7 as eluent to give $4 \mathrm{c}$ as a yellow oil, yield: $78 \% .{ }^{1} \mathrm{H}$ NMR $\left(\mathrm{CDCl}_{3}\right)$ $\delta: 3.88(\mathrm{~s}, 3 \mathrm{H}), 3.92(\mathrm{~s}, 6 \mathrm{H}), 3.96(\mathrm{~s}, 3 \mathrm{H}), 7.12(\mathrm{~m}, 2 \mathrm{H}), 7.33(\mathrm{~s}, 2 \mathrm{H})$, $7.49(\mathrm{~s}, 1 \mathrm{H}), 7.51(\mathrm{~d}, J=8.4 \mathrm{~Hz}, 1 \mathrm{H})$. Anal. Calcd for $\mathrm{C}_{19} \mathrm{H}_{18} \mathrm{O}_{5} \mathrm{~S}: \mathrm{C}$, 63.76; H, 5.06. Found: C, 63.61; H, 4.89 .

\subsection{4. (6-Methoxybenzo[b]thiophen-2-yl)(3,4,5-trimethoxy- phenyl)methanone (4d)}

The residue was chromatographed with EtOAc-petroleum ether 2:8 as eluent to give $\mathbf{4 d}$ as a white solid, yield: $63 \%, \mathrm{mp} 114$ $116{ }^{\circ} \mathrm{C} .{ }^{1} \mathrm{H}$ NMR $\left(\mathrm{CDCl}_{3}\right) \delta: 3.92(\mathrm{~s}, 3 \mathrm{H}), 3.93(\mathrm{~s}, 6 \mathrm{H}), 3.95(\mathrm{~s}, 3 \mathrm{H})$, 7.03 (dd, $J=8.8$ and $2.4 \mathrm{~Hz}, 1 \mathrm{H}), 7.16(\mathrm{~s}, 2 \mathrm{H}), 7.34(\mathrm{~d}, J=2.0 \mathrm{~Hz}$ $1 \mathrm{H}), 7.76(\mathrm{~d}, J=8.8 \mathrm{~Hz}, 1 \mathrm{H}), 7.83(\mathrm{~d}, J=1.0 \mathrm{~Hz}, 1 \mathrm{H})$. Anal. Calcd for $\mathrm{C}_{19} \mathrm{H}_{18} \mathrm{O}_{5} \mathrm{~S}$ : C, 63.76; $\mathrm{H}, 5.06$. Found: $\mathrm{C}, 63.62 ; \mathrm{H}, 4.78$.

\subsection{5. (7-Methoxybenzo[b]thiophen-2-yl)(3,4,5-trimethoxy- phenyl)methanone (4e)}

The residue was chromatographed with EtOAc-petroleum ether $2: 8$ as eluent to give $\mathbf{4 e}$ as a yellow solid, yield: $68 \%$, mp 105$107{ }^{\circ} \mathrm{C} .{ }^{1} \mathrm{H}$ NMR $\left(\mathrm{CDCl}_{3}\right) \delta: 3.92(\mathrm{~s}, 3 \mathrm{H}), 3.96(\mathrm{~s}, 6 \mathrm{H}), 4.03(\mathrm{~s}, 3 \mathrm{H})$, $6.89(\mathrm{~d}, J=7.2 \mathrm{~Hz}, 1 \mathrm{H}), 7.20(\mathrm{~s}, 2 \mathrm{H}), 7.38(\mathrm{t}, J=8.0 \mathrm{~Hz}, 1 \mathrm{H}), 7.52$ $(\mathrm{d}, J=8.0 \mathrm{~Hz}, 1 \mathrm{H}), 7.92(\mathrm{~s}, 1 \mathrm{H})$. Anal. Calcd for $\mathrm{C}_{19} \mathrm{H}_{18} \mathrm{O}_{5} \mathrm{~S}: \mathrm{C}$, 63.76; H, 5.06. Found: C, 63.61; H, 4.92. 
5.7.6. (3,4,5-Trimethoxyphenyl)(3-methylbenzo[b]thiophen-2yl)methanone (4f)

The residue was chromatographed with EtOAc-petroleum ether $1: 9$ as eluent to give $\mathbf{4 f}$ as a white solid, yield: $56 \%, \mathrm{mp} 124-126{ }^{\circ} \mathrm{C}$. ${ }^{1} \mathrm{H}$ NMR $\left(\mathrm{CDCl}_{3}\right) \delta$ : $2.61(\mathrm{~s}, 3 \mathrm{H}), 3.89(\mathrm{~s}, 6 \mathrm{H}), 3.95(\mathrm{~s}, 3 \mathrm{H}), 7.20(\mathrm{~s}$, $2 \mathrm{H}), 7.43(\mathrm{~m}, 2 \mathrm{H}), 7.90(\mathrm{~m}, 2 \mathrm{H})$. Anal. Calcd for $\mathrm{C}_{19} \mathrm{H}_{18} \mathrm{O}_{4} \mathrm{~S}: \mathrm{C}$, $66.65 ; \mathrm{H}, 5.30$. Found: $\mathrm{C}, 66.51 ; \mathrm{H}, 5.18$.

\subsection{7. (4-Methoxy-4-methylbenzo[b]thiophen-2-yl)(3,4,5-trime-} thoxyphenyl)methanone (4g)

The residue was chromatographed with EtOAc-petroleum ether $1: 9$ as eluent to give $4 \mathrm{~g}$ as a white solid, yield: $60 \%, \mathrm{mp} 160-162{ }^{\circ} \mathrm{C}$. ${ }^{1} \mathrm{H} \mathrm{NMR}\left(\mathrm{CDCl}_{3}\right) \delta: 2.73$ (s, 3H), 3.89 (s, 6H), 3.94 (s, 6H), 6.73 (dd, $J=7.6$ and $1.0 \mathrm{~Hz}, 1 \mathrm{H}), 7.18(\mathrm{~s}, 2 \mathrm{H}), 7.38(\mathrm{~m}, 2 \mathrm{H})$. Anal. Calcd for $\mathrm{C}_{20} \mathrm{H}_{20} \mathrm{O}_{5} \mathrm{~S}$ : C, 64.50; $\mathrm{H}, 5.41$. Found: C, 64.38; $\mathrm{H}, 5.23$.

\subsection{8. (5-Methoxy-3-methylbenzo[b]thiophen-2-yl)(3,4,5-trime-} thoxyphenyl)methanone (4h)

The residue was chromatographed with EtOAc-petroleum ether $1: 9$ as eluent to give $\mathbf{4 h}$ as a white solid yield: $52 \%, \mathrm{mp} 132-133^{\circ} \mathrm{C}$. ${ }^{1} \mathrm{H}$ NMR $\left(\mathrm{CDCl}_{3}\right) \delta: 2.58(\mathrm{~s}, 3 \mathrm{H}), 3.89(\mathrm{~s}, 3 \mathrm{H}), 3.92(\mathrm{~s}, 3 \mathrm{H}), 3.94(\mathrm{~s}$, $3 \mathrm{H}), 3.96(\mathrm{~s}, 3 \mathrm{H}), 7.11(\mathrm{~d}, J=8.8 \mathrm{~Hz}, 1 \mathrm{H}), 7.20(\mathrm{~s}, 2 \mathrm{H}), 7.24(\mathrm{~s}, 1 \mathrm{H})$, $7.72(\mathrm{~d}, J=8.8 \mathrm{~Hz}, 1 \mathrm{H})$. Anal. Calcd for $\mathrm{C}_{20} \mathrm{H}_{20} \mathrm{O}_{5} \mathrm{~S}: \mathrm{C}, 64.50 ; \mathrm{H}$, 5.41. Found: C, 64.32; H, 5.21.

5.7.9. (6-Methoxy-3-methylbenzo[b]thiophen-2-yl)(3,4,5-trimethoxyphenyl)methanone (4i)

The residue was chromatographed with EtOAc-petroleum ether 1.5:8.5 as eluent to give $\mathbf{4 i}$ as a white solid, yield: $60 \%, \mathrm{mp} 130$ $132{ }^{\circ} \mathrm{C} .{ }^{1} \mathrm{H} \mathrm{NMR}\left(\mathrm{CDCl}_{3}\right) \delta: 2.59(\mathrm{~s}, 3 \mathrm{H}), 3.89(\mathrm{~s}, 3 \mathrm{H}), 3.91(\mathrm{~s}, 3 \mathrm{H})$, $3.92(\mathrm{~s}, 3 \mathrm{H}), 3.94(\mathrm{~s}, 3 \mathrm{H}), 7.11(\mathrm{~d}, J=2.8$ and $8.8 \mathrm{~Hz}, 1 \mathrm{H}), 7.17(\mathrm{~s}$, $2 \mathrm{H}), 7.39(\mathrm{~s}, 1 \mathrm{H}), 7.74(\mathrm{~d}, J=8.8 \mathrm{~Hz}, 1 \mathrm{H})$. Anal. Calcd for $\mathrm{C}_{20} \mathrm{H}_{20} \mathrm{O}_{5} \mathrm{~S}$ : C, 64.50; $\mathrm{H}, 5.41$. Found: C, 64.33; H, 5.19.

\subsubsection{0. (7-Methoxy-3-methylbenzo[b]thiophen-2-yl)(3,4,5-} trimethoxyphenyl)methanone $(4 \mathbf{j})$

The residue was chromatographed with EtOAc-petroleum ether $3: 7$ as eluent to give $\mathbf{4 j}$ as a yellow solid, yield: $71 \%, \mathrm{mp} 112-$ $114{ }^{\circ} \mathrm{C} .{ }^{1} \mathrm{H} \mathrm{NMR}\left(\mathrm{CDCl}_{3}\right) \delta: 2.43(\mathrm{~s}, 3 \mathrm{H}), 3.89(\mathrm{~s}, 3 \mathrm{H}), 3.94(\mathrm{~s}, 6 \mathrm{H})$, $3.98(\mathrm{~s}, 3 \mathrm{H}), 6.87(\mathrm{~d}, J=7.2 \mathrm{~Hz}, 1 \mathrm{H}), 7.12(\mathrm{~s}, 2 \mathrm{H}), 7.42(\mathrm{t}$, $J=8.0 \mathrm{~Hz}, 1 \mathrm{H}), 7.54(\mathrm{~d}, J=8.0 \mathrm{~Hz}, 1 \mathrm{H})$. Anal. Calcd for $\mathrm{C}_{20} \mathrm{H}_{20} \mathrm{O}_{5} \mathrm{~S}$ : C, 64.50; H, 5.41. Found: C, 64.32; H, 5.20.

\subsubsection{1. (5,6-Dimethoxybenzo[b]thiophen-2-yl)(3,4,5-trime- thoxyphenyl)methanone (4k)}

The residue was chromatographed with EtOAc-petroleum ether 4:6 as eluent to give 4k as a yellow solid, yield: $62 \%, \mathrm{mp} 153-$ $155^{\circ} \mathrm{C} .{ }^{1} \mathrm{H}$ NMR $\left(\mathrm{CDCl}_{3}\right) \delta: 3.93(\mathrm{~s}, 6 \mathrm{H}), 3.95(\mathrm{~s}, 6 \mathrm{H}), 4.00(\mathrm{~s}, 3 \mathrm{H})$, $7.17(\mathrm{~s}, 2 \mathrm{H}), 7.26(\mathrm{~s}, 1 \mathrm{H}), 7.30(\mathrm{~s}, 1 \mathrm{H}), 7.80(\mathrm{~s}, 1 \mathrm{H})$. Anal. Calcd for $\mathrm{C}_{20} \mathrm{H}_{20} \mathrm{O}_{6} \mathrm{~S}$ : C, 61.84; H, 5.19. Found: C, 61.62; H, 5.02.

\subsubsection{2. (6-Ethoxy-3-methylbenzo[b]thiophen-2-yl)(3,4,5-trime- thoxyphenyl)methanone (41)}

The residue was chromatographed with EtOAc-petroleum ether 3:7 as eluent to give $\mathbf{4 1}$ as a red solid, yield: $64 \%, \mathrm{mp} 157-158{ }^{\circ} \mathrm{C} .{ }^{1} \mathrm{H}$ $\operatorname{NMR}\left(\mathrm{CDCl}_{3}\right) \delta: 1.50(\mathrm{t}, J=7.2 \mathrm{~Hz}, 3 \mathrm{H}), 2.58(\mathrm{~s}, 3 \mathrm{H}), 3.89(\mathrm{~s}, 6 \mathrm{H})$, $3.94(\mathrm{~s}, 3 \mathrm{H}), 4.14(\mathrm{t}, J=6.8 \mathrm{~Hz}, 2 \mathrm{H}), 7.10(\mathrm{~d}, J=2.8$ and $8.6 \mathrm{~Hz}$, $1 \mathrm{H}), 7.16(\mathrm{~s}, 2 \mathrm{H}), 7.29(\mathrm{~s}, 1 \mathrm{H}), 7.75(\mathrm{~d}, J=8.8 \mathrm{~Hz}, 1 \mathrm{H})$. Anal. Calcd for $\mathrm{C}_{21} \mathrm{H}_{22} \mathrm{O}_{5} \mathrm{~S}$ : C, 65.27; H, 5.74. Found: C, 65.01; H, 5.62.

\subsubsection{3. (6-Fluoro-3-methylbenzo[b]thiophen-2-yl)(3,4,5-trime-} thoxyphenyl)methanone $(4 \mathrm{~m})$

The residue was chromatographed with EtOAc-petroleum ether 3:7 as eluent to give $\mathbf{4 m}$ as a white solid, yield: 95\%, mp 130$132{ }^{\circ} \mathrm{C} .{ }^{1} \mathrm{H} \mathrm{NMR}\left(\mathrm{CDCl}_{3}\right) \delta: 2.60(\mathrm{~s}, 3 \mathrm{H}), 3.90(\mathrm{~s}, 6 \mathrm{H}), 3.96(\mathrm{~s}, 3 \mathrm{H})$, $7.16(\mathrm{~s}, 2 \mathrm{H}), 7.23(\mathrm{~m}, 1 \mathrm{H}), 7.52(\mathrm{dd}, J=2.6$ and $8.8 \mathrm{~Hz}, 1 \mathrm{H}), 7.84$ (dd, $J=5.6$ and $8.6 \mathrm{~Hz}, 1 \mathrm{H}$ ). Anal. Calcd for $\mathrm{C}_{19} \mathrm{H}_{17} \mathrm{FO}_{4} \mathrm{~S}$ : C, 63.32; $\mathrm{H}, 4.75$. Found: $\mathrm{C}, 63.11 ; \mathrm{H}, 4.56$.

\subsection{Cell growth inhibitory activity}

Murine leukemia L1210, murine mammary carcinoma FM3A and human T-lymphocyte Molt 4 and CEM and human cervix carcinoma (HeLa) cells were suspended at 300,000-500,000 cells/mL of culture medium, and $100 \mu \mathrm{L}$ of a cell suspension was added to $100 \mu \mathrm{L}$ of an appropriate dilution of the test compounds in wells of 96 -well microtiter plates. After incubation at $37^{\circ} \mathrm{C}$ for two days, cell number was determined using a Coulter counter. The $\mathrm{IC}_{50}$ value was defined as the compound concentration required to inhibit cell proliferation by $50 \%$.

\subsection{Effects on tubulin polymerization and on colchicine binding to tubulin}

Bovine brain tubulin was purified as described previously. ${ }^{15}$ To evaluate the effect of the compounds on tubulin assembly in vitro, ${ }^{11}$ varying concentrations were preincubated with $10 \mu \mathrm{M}$ tubulin in glutamate buffer at $30^{\circ} \mathrm{C}$ and then cooled to $0^{\circ} \mathrm{C}$. After addition of GTP, the mixtures were transferred to $0^{\circ} \mathrm{C}$ cuvettes in a recording spectrophotometer and warmed to $30^{\circ} \mathrm{C}$, and the assembly of tubulin was observed turbidimetrically. The $\mathrm{IC}_{50}$ value was defined as the compound concentration that inhibited the extent of assembly by $50 \%$ after a $20 \mathrm{~min}$ incubation. The ability of the test compounds to inhibit colchicine binding to tubulin was measured as described, ${ }^{15}$ except that the reaction mixtures contained $1 \mu \mathrm{M}$ tubulin, $5 \mu \mathrm{M}\left[{ }^{3} \mathrm{H}\right]$ colchicine and $1 \mu \mathrm{M}$ or $5 \mu \mathrm{M}$ test compound.

\subsection{Flow cytometric analysis of cell cycle distribution}

For details, see Ref. 8a.

\subsection{Molecular modeling}

All molecular modeling studies were performed on a MacPro dual $2.66 \mathrm{GHz}$ Xeon running Ubuntu 8. The tubulin structure was downloaded from the PDB data bank (http://www. rcsb.org/-PDB code: $1 \mathrm{SA0}) .{ }^{16}$ Hydrogen atoms were added to the protein, using Molecular Operating Environment (MOE) 2009.10, ${ }^{17}$ and minimized keeping all the heavy atoms fixed until a RMSD gradient of $0.05 \mathrm{kcal} \mathrm{mol}^{-1} \AA^{-1}$ was reached. Ligand structures were built with MOE and minimized using the MMFF94x forcefield until a RMSD gradient of $0.05 \mathrm{kcal} \mathrm{mol}^{-1} \AA^{-1}$ was reached. The docking simulations were performed using Flex $\mathrm{X}^{18}$ with the MOE interface.

\section{Acknowledgments}

Financial support was provided by GOA (Krediet no. 10/014) of the K. U. Leuven. The authors would like to thank Mrs. Lizette van Berckelaer, Dr. Alberto Casolari and Elisa Durini for technical assistance.

\section{Supplementary data}

Supplementary data associated with this article can be found, in the online version, at doi:10.1016/j.bmc.2010.05.068.

\section{References and notes}

1. (a) Worderman, L.; Mitchison, T. J. Dynamics of Microtubule Assembly In vivo. In Microtubules; Hyams, J., Lloyd, C., Eds.; Wiley_Liss, Inc: New York, 1994; (b) Hearn, B. R.; Shaw, S. J.; Myles, D. C. Compr. Med. Chem. II 2007, 7, 81; (c) Pasquier, E.; Andrè, N.; Braguer, D. Curr. Cancer Drug Targets 2007, 7, 566. 
2. (a) Pellegrinelli, F.; Budman, D. R. Cancer Invest. 2005, 23, 264; (b) Chaplin, D. J.; Horsman, M. R.; Siemann, D. W. Curr. Opin. Invest. Drugs 2006, 7, 522; (c) Walczak, C. E. Curr. Opin. Cell Biol. 2000, 12, 52.

3. (a) Hadfield, J. A.; Ducki, S.; Hirst, N.; McGown, A. T. Prog. Cell Cycle Res. 2003, 5 , 309; (b) Ducki, S. Anticancer Agents Med. Chem. 2009, 9, 336; (c) Kiselyov, A.; Bulakin, K. V. Anticancer Agents Med. Chem. 2007, 7, 189.

4. Pettit, G. R.; Singh, S. B.; Hamel, E.; Lin, C. M.; Alberts, D. S.; Garcia-Kendall, D. Experientia 1989, 45, 209.

5. Lin, C. M.; Ho, H. H.; Pettit, G. R.; Hamel, E. Biochemistry 1989, 28, 6984.

6. (a) Tron, G. C.; Pirali, T.; Sorba, G.; Pagliai, F.; Busacca, S.; Genazzani, A. A. J. Med. Chem. 2006, 49, 3033; (b) Mahindroo, N.; Liou, J. P.; Chang, J. Y.; Hsieh, H. P. Expert Opin. Ther. Patents 2006, 16, 647; (c) Chaudhary, A.; Pandeya, S. N.; Kumar, P.; Sharma, P. P.; Gupta, S.; Soni, N.; Verma, K. K.; Bhardwaj, G. Mini-Rev. Med. Chem. 2007, 7, 1186; (d) Hsie, H. P.; Liou, J. P.; Mahindroo, N. Curr. Pharm. Des. 2005, 11, 1655 .

7. (a) Pinney, K. G.; Bounds, A. D.; Dingerman, K. M.; Mocharla, V. P.; Pettit, G. R.; Bai, R.; Hamel, E. Bioorg. Med. Chem. Lett. 1999, 9, 1081; (b) Flynn, B. L.; VerdierPinard, P.; Hamel, E. Org. Lett. 2001, 3, 651.

8. (a) Romagnoli, R.; Baraldi, P. G.; Carrion, M. D.; Lopez Cara, C.; Preti, D. Fruttarolo, F.; Pavani, M. G.; Tabrizi, M. A.; Tolomeo, M.; Grimaudo, S.; Di Antonella, C.; Balzarini, J.; Hadfield, J. A.; Brancale, A.; Hamel, E. J. Med. Chem. 2007, 50, 2273; (b) Romagnoli, R.; Baraldi, P. G.; Jung, M. K.; Iaconinoto, M. A.;
Carrion, M. D.; Preti, D.; Tabrizi, M. A.; Fruttarlo, F.; De Clercq, E.; Balzarini, J.; Hamel, E. Bioorg. Med. Chem. Lett. 2005, 15, 4048.

9. For a review on the mechanism and application of Newman-Kwart rearrangement see: Lloyd-Jones, G. C.; Moseley, J. D.; Renny, J. S. Synthesis 2008, 5, 661.

10. Beck, J. R. J. Heterocycl. Chem. 1978, 15, 513.

11. Hamel, E. Cell Biochem. Biophys. 2003, 38, 1

12. Verdier-Pinard, P.; Lai, J.-Y.; Yoo, H.-D.; Yu, J.; Marquez, B.; Nagle, D. G.; Nambu, M.; White, J. D.; Falck, J. R.; Gerwick, W. H.; Day, B. W.; Hamel, E. Mol. Pharmacol. 1998, 53, 62.

13. (a) Lozzio, C. B.; Lozzio, B. B. Blood 1975, 45, 321; (b) Viola, G.; Vedaldi, D.; Dall'acqua, F.; Fortunato, E.; Basso, G.; Bianchi, N.; Zuccato, C.; Borgatti, M. Lampronti, I.; Gambari, R. Biochem. Pharmacol. 2008, 75, 810.

14. Romagnoli, R.; Baraldi, P. G.; Carrion, M. D.; Lopez-Cara, C.; Cruz-Lopez, O.; Tolomeo, M.; Grimaudo, S.; Di Cristina, A.; Pipitone, M. R.; Balzarini, J.; Zonta, N.; Brancale, A.; Hamel, E. Bioorg. Med. Chem. 2009, 17, 6862.

15. Hamel, E.; Lin, C. M. Biochemistry 1984, 23, 4173.

16. Ravelli, R. B. G.; Gigant, B.; Curmi, P. A.; Jourdain, I.; Lachkar, S.; Sobel, A.; Knossow, M. Nature 2004, 428, 198.

17. Molecular Operating Environment (MOE 2007.09). Chemical Computing Group, Inc. Montreal, Quebec, Canada. http://www.chemcomp.com.

18. FlexX 3.0. BioSolveIT GmbH, Sankt Augustin, Germany. http://www.biosolveit.de. 